\title{
Reversing land degradation through grasses: a systematic meta-analysis in the Indian tropics
}

\author{
Debashis Mandal $^{1}$, Pankaj Srivastava ${ }^{1}$, Nishita Giri ${ }^{1}$, Rajesh Kaushal ${ }^{1}$, Artemi Cerda ${ }^{2}$, and Nurnabi Meherul Alam ${ }^{1}$ \\ ${ }^{1}$ ICAR-Indian Institute of Soil and Water Conservation 218, Kaulagarh Road, Dehradun-248195, Uttarakhand, India \\ ${ }^{2}$ Department of Geography, University of Valencia, Blasco Ibañez, Valencia, Spain \\ Correspondence to: Debashis Mandal (dmandalcswcrti@gmail.com) and Pankaj Srivastava (pksnbri@gmail.com)
}

Received: 14 October 2016 - Discussion started: 21 October 2016

Revised: 13 January 2017 - Accepted: 20 January 2017 - Published: 22 February 2017

\begin{abstract}
Although intensive agriculture is necessary to sustain the world's growing population, accelerated soil erosion contributes to a decrease in the environmental health of ecosystems at local, regional and global scales. Reversing the process of land degradation using vegetative measures is of utmost importance in such ecosystems. The present study critically analyzes the effect of grasses in reversing the process of land degradation using a systematic review. The collected information was segregated under three different land use and land management situations. Meta-analysis was applied to test the hypothesis that the use of grasses reduces runoff and soil erosion. The effect of grasses was deduced for grass strip and in combination with physical structures. Similarly, the effects of grasses were analyzed in degraded pasture lands. The overall result of the meta-analysis showed that infiltration capacity increased approximately 2-fold after planting grasses across the slopes in agricultural fields. Grazing land management through a cut-and-carry system increased conservation efficiencies by 42 and $63 \%$ with respect to reduction in runoff and erosion, respectively. Considering the comprehensive performance index (CPI), it has been observed that hybrid Napier (Pennisetum purpureum) and sambuta (Saccharum munja) grass seem to posses the most desirable attributes as an effective grass barrier for the western Himalayas and Eastern Ghats, while natural grass (Dichanthium annulatum) and broom grass (Thysanolaena maxima) are found to be most promising grass species for the Konkan region of the Western Ghats and the northeastern Himalayan region, respectively. In addition to these benefits, it was also observed that soil carbon loss can be reduced by $83 \%$ with the use of grasses. Overall, efficacy for erosion control of various grasses was more than $60 \%$; hence, their
\end{abstract}

selection should be based on the production potential of these grasses under given edaphic and agro-ecological conditions. The present analysis also indicated that grass must be used as a vegetative strip to maintain soil quality in sloppy arable areas (8.5 Mha) of Indian hilly regions. Similarly, due attention should be paid for establishing grasses in 3 Mha of degraded pasture lands and 3.5 Mha of shifting cultivation areas in India to reverse the land degradation.

\section{Introduction}

Water erosion is the main cause of land degradation, affecting an area of about 2 billion ha throughout the world, with the largest part in tropics, and affecting the two most important natural resources, namely soil and water (Mandal and Sharda, 2011a; De Oliveria et al., 2010; Keesstra et al., 2014; Novara et al., 2011, 2016; Seutloali and Beckedahl, 2015). Worldwide loss of water and sediment due to soil erosion is a major environmental threat (Prosdocimi et al., 2016; Pimentel, 1993). Soil erosion is accelerated due to high rainfall intensities (Keesstra et al., 2016), steep slopes (Beskow et al., 2009) and the fragile nature of topsoil (Lal, 1998; Rodrigo Comino et al., 2016; Ochoa et al., 2016). Many parts of the tropics in India have high annual rainfall confined to only 4 to 5 months (June-September). During the 7-8-month dry period, scarcity of water causes a severe shortage of fodder in farmlands, which leads to an increase in grazing pressure on forest and community lands. Nearly a third of the fodder requirement in India is met through forest resources in the form of grazing and cut fodder (MoEF, 1999). The process of land degradation in croplands and grasslands has been ac- 
celerated mainly by inappropriate land use (Nearing et al., 2005; Mandal et al., 2010) and mismanagement (Kagabo et al., 2013).

Generally, soil conservation planning requires knowledge of soil loss tolerance values, which show the higher limit of soil erosion rate that can be allowed without long-term land degradation (Jha et al., 2009). Strategies to reverse land degradation are critical since soil is a non-renewable resource (Mandal and Sharda, 2011b; Mandal et al., 2010). Soil erosion rates more than tolerance values are considered unacceptable (Mandal and Sharda, 2013), which leads to irreversible land degradation and need to be reduced through appropriate soil conservation measures (SCMs) (Biswas et al., 2015) The physical structures to check soil erosion are proven effective but are cost-intensive. Biological methods of soil and water conservation, especially grass-based methods, have been reported to be very cost-effective and suitable for sloppy lands. Perennial grasses provide ground cover throughout the year and help in reducing runoff and soil loss when used as barriers along the contour, particularly in hill slopes (Dhruvanarayana and Rambabu, 1983). Grasses are the key component in many ecosystems of the world (ParrasAlcántara et al., 2015; Hu et al., 2016; Mekonnen et al., 2016).

Grass species, in particular, have tremendous potentialities in soil conservation as grass roots have a great binding influence on soil particles (Novara et al., 2013; Ola et al., 2015). Due to resource scarcity and multiple competing enterprises that characterize most farming situations of rural India, farmers often lack the adequate resources to invest in physical soil conservation structures. Thus, the usefulness of grasses as a vegetative barrier is an alternative to the physical soil structures. Basically, these contour vegetative barriers/grass filter strips help in reducing soil erosion by acting as porous barriers which subsequently slow down the flow of runoff (Anigma, 2002; Mutegi et al., 2008).

The hilly region of India is characterized by geological fragility, land marginality and vulnerability (Mandal and Sharda, 2013). The croplands in sloppy areas suffer from excessive soil erosion and erosion-induced nutrient depletion. Soil erosion in these areas ranges between 20 and $40 \mathrm{Mg} \mathrm{ha}^{-1} \mathrm{yr}^{-1}$ as compared to the national average of 16.35 $\mathrm{Mg} \mathrm{ha}^{-1} \mathrm{yr}^{-1}$ (Dhruvanarayana and Rambabu, 1983). Such high rates of soil erosion result in considerable depletion of nutrients from the topsoil, which in turn causes poor productivity of crops. Research evidence from the land subjected to shifting cultivation reported that about $600 \mathrm{Mt}$ of soil is eroded annually, which led to losses of 258000 , 73000 and $179000 \mathrm{t}$ of $\mathrm{N}, \mathrm{P}_{2} \mathrm{O}_{5}$ and $\mathrm{K}_{2} \mathrm{O}$, respectively (Kumar, 2011). Soil erosion has been pointed to as one of the important reasons for abandonment of land by many farmers in subtropical hilly areas of India (Rao and Pant, 2001).

The grasslands in the middle and lower Himalayas are generally in the most neglected state with low productivity. In this predominantly grazing region, excessive reliance on animal husbandry under a growing population has exerted great pressure on the land. In tropical India, an average of 42 animals graze on a hectare of land compared to maximum threshold level of 5 animals (Sahay, 1999). Raising and maintenance of perennial grasses on degraded soils has been suggested as a means to improve soil quality and sequester carbon in the soil. Several studies have shown that the inclusion of grasses in the agricultural landscape often improves the productivity of system while providing opportunities to create carbon (C) sinks (Ghosh et al., 2009; Cogle et al., 2011; Huang et al., 2010; Mutegi et al., 2008). Soils typically account for $70-90 \%$ of the total carbon sequestered in a grassland ecosystem (Batjes, 2001).

In India most of the studies on the role of grasses as vegetative/filter strips have been done in isolation with fewer slope categories and with limited objectives restricted to soil erosion (Njoroge and Rao, 1994). Similarly, studies on grazing land management are also very scarce. We present here an analysis of the potential of grasses for reversing land degradations for which the meta-analysis was carried out. The objective of this study is to determine the effect of grasses in arresting soil loss; runoff, moisture conservation and carbon buildup in soils. Based on such information, conclusions regarding reversing land degradation through grasses can be drawn wherever similar land conditions are known.

\section{Material and methods}

Information on the usefulness of grasses in soil and water conservation was collected from published literature (Table 1a and b). Keeping in mind the role of grasses for arresting soil loss and runoff, all data were reoriented under three different categories, namely (i) the role of grasses as a vegetative barrier, (ii) the complementary role of grasses with physical soil structures and (iii) management of grazing lands. A total of 83 studies comprising 19 different sites in varied agro-climatic region were included in the data set for the analysis (Table 1a and b). Fifty-four of these studies were related to contour grass barrier (CGB), 12 were related to grazing and 17 were related to complementary role of grasses.

Meta-analysis was applied to test the hypotheses about role of grasses in reducing soil erosion by combining data from several experiments. The technique has been extensively used in natural resource management studies (Ilstect et al., 2007, Poeplau and Don, 2015; Osenberg et al., 1999).

We aim to synthesize and discuss the past scientific studies pertaining to the effect of grasses in arable and non-arable lands on one of the key determining soil processes, namely reduction in soil and water losses and enhancement of infiltration. In order to produce a combined data set, due care was given to select the studies where both reference site (bare land/fallow land) and grass treatments were present. The 
Table 1. (a) Details of the experiments and sources of data used in the study. (b) Details of the experiments and sources of data used to assess relative merits of different contour grass barriers (CGBs).

\begin{tabular}{|c|c|c|c|c|c|c|c|}
\hline \multirow{2}{*}{$\begin{array}{l}\text { (a) } \\
\text { Vegetative } \\
\text { barrier }\end{array}$} & \multicolumn{3}{|c|}{ With CGB } & \multicolumn{2}{|c|}{ Without CGB } & \multirow[t]{2}{*}{ Soil type and climate } & \multirow[t]{2}{*}{ Source } \\
\hline & $\begin{array}{l}\text { Name of } \\
\text { grasses }\end{array}$ & $\begin{array}{r}\text { Soil loss } \\
\left(\mathrm{Mg} \mathrm{ha}^{-1} \mathrm{yr}^{-1}\right)\end{array}$ & $\begin{array}{r}\text { Runoff } \\
(\%)\end{array}$ & $\begin{array}{r}\text { Soil loss } \\
\left(\mathrm{Mg} \mathrm{ha}^{-1} \mathrm{yr}^{-1}\right)\end{array}$ & $\begin{array}{r}\text { Runoff } \\
(\%)\end{array}$ & & \\
\hline & \multirow[t]{3}{*}{$\begin{array}{l}\text { Dichanthium } \\
\text { annulatum }\end{array}$} & 1.0 & - & 16.68 & - & $\begin{array}{l}\text { Red soil (Rhodustalfs), } \\
\text { hot subhumid }\end{array}$ & Lal et al. (2004) \\
\hline & & 4.2 & 33 & 10.8 & 48 & Inceptisols, semiarid & Rao and Pande (2014) \\
\hline & & 0.1 & 7.7 & 6.35 & 64.8 & Red, hot subhumid & Sharma (1999) \\
\hline & $\begin{array}{l}\text { Tripsacum } \\
\text { laxum }\end{array}$ & - & 19 & 19 & 29 & $\begin{array}{l}\text { Red (laterite), } \\
\text { warm subhumid }\end{array}$ & Madhu et al. (2004) \\
\hline & \multirow{4}{*}{$\begin{array}{l}\text { Panicum } \\
\text { maximum }\end{array}$} & 2.47 & 20.7 & 8.1 & 40.9 & Alluvial, subtropical & Sharda et al. (2002) \\
\hline & & 5.62 & 34.3 & 20.6 & 48.3 & Alluvial, subtropical & Ojasvi et al. (2000) \\
\hline & & 7.54 & 28.6 & 30.9 & 37.9 & Alluvial, subtropical & Ojasvi et al. (2000) \\
\hline & & 7.93 & 17.04 & 15.26 & 22.79 & Alluvial, subtropical & Khola (2000) \\
\hline & \multirow[t]{7}{*}{ Natural } & 2.17 & 35.08 & 5.08 & 54.5 & Alluvial, subtropical & Aggarwal et al. (2000) \\
\hline & & 0.5 & 22.7 & 1.05 & 49.6 & Laterite, hot subhumid & Rao et al. (1998) \\
\hline & & 1.37 & 39.9 & 2.16 & 54.8 & Laterite, hot subhumid & Rao et al. (1998) \\
\hline & & 1.02 & 44.1 & 1.72 & 59.1 & Laterite, hot subhumid & Rao et al. (1998) \\
\hline & & 0.59 & 5.87 & 3.12 & 12.08 & & Kale et al. (1993) \\
\hline & & 0.76 & 10.2 & 4.4 & 16.95 & & Kale et al. (1993) \\
\hline & & 1.36 & 13.36 & 4.84 & 20.1 & & Kale et al. (1993) \\
\hline & \multirow{3}{*}{$\begin{array}{l}\text { Cenchrus } \\
\text { ciliaris }\end{array}$} & 0.6 & 16.25 & 7.05 & 46 & Black (Inceptisol) & Nalatwadmath et al. (2000) \\
\hline & & 0.81 & 21.9 & 1.39 & 29.5 & Hot semiarid & Katiyar et al. (2007a) \\
\hline & & 0.5 & 6.6 & 16.08 & 68.7 & Red, hot subhumid & Sharma (1999) \\
\hline & \multirow{4}{*}{$\begin{array}{l}\text { Vetiveria } \\
\text { zizanioides }\end{array}$} & 9.02 & 19.17 & 15.26 & 22.79 & Alluvial, subtropical & Khola (2000) \\
\hline & & 0.29 & 7.29 & 0.53 & 11.26 & Red, hot subhumid & Katiyar et al. (2007b) \\
\hline & & 1.29 & 25.4 & 6.35 & 64.8 & Red, hot subhumid & Sharma (1999) \\
\hline & & 0.5 & 8.6 & 0.7 & 20.7 & Red, hot subhumid & Sharma and Bhatt (1996) \\
\hline & \multirow{2}{*}{$\begin{array}{l}\text { Thysanolaena } \\
\text { maxima } \\
\text { (broom) }\end{array}$} & 15.7 & 14.2 & 19 & 17 & Red laterite (Alfisol) & Sahoo and Adhikari (2014) \\
\hline & & 18.7 & 17.3 & 23.9 & 23.5 & Hot subhumid & Sahoo and Adhikari (2014) \\
\hline & $\begin{array}{l}\text { Heteropogon } \\
\text { hamata }\end{array}$ & 0.59 & 20.8 & 1.39 & 29.5 & $\begin{array}{l}\text { Red laterite (Alfisol) } \\
\text { Hot subhumid }\end{array}$ & Katiyar et al. (2007a) \\
\hline \multicolumn{8}{|c|}{ Grassland management } \\
\hline \multirow[t]{11}{*}{ Grass } & \multicolumn{3}{|c|}{ Grass improvement } & \multicolumn{2}{|c|}{ Traditional grass } & Soil type and climate & Source \\
\hline & Species & $\begin{array}{r}\text { Soil loss } \\
\left(\mathrm{Mg} \mathrm{ha}^{-1} \mathrm{yr}^{-1}\right)\end{array}$ & $\begin{array}{r}\text { Runoff } \\
(\%)\end{array}$ & $\begin{array}{r}\text { Soil loss } \\
\left(\mathrm{Mg} \mathrm{ha}^{-1} \mathrm{yr}^{-1}\right)\end{array}$ & $\begin{array}{r}\text { Runoff } \\
(\%)\end{array}$ & & \\
\hline & $\begin{array}{l}\text { Cynodon } \\
\text { dactylon }\end{array}$ & 0.06 & 35 & 3.28 & 54 & Red, hot subhumid & Hazra and Singh (1986) \\
\hline & Cenchrus & 0.13 & 33 & 3.28 & 28.12 & Red, hot subhumid & Hazra and Singh (1986) \\
\hline & ciliaris & 2.14 & 16.8 & 3.33 & & Black, hot semiarid & Ilango et al. (2002) \\
\hline & $\begin{array}{l}\text { Panicum } \\
\text { antidotale }\end{array}$ & 0.43 & 36 & 3.28 & 54 & Red, hot subhumid & Hazra and Singh (1986) \\
\hline & $\begin{array}{l}\text { Pennisetum } \\
\text { polystachyon }\end{array}$ & 0.07 & 27 & 3.28 & 54 & Red, hot subhumid & Hazra and Singh (1986) \\
\hline & $\begin{array}{l}\text { Urochloa } \\
\text { stolonifera }\end{array}$ & 0.08 & 32 & 3.28 & 54 & Red, hot subhumid & Hazra and Singh (1986) \\
\hline & $\begin{array}{l}\text { Cymbopogon } \\
\text { martinii }\end{array}$ & 1.08 & 11.32 & 3.33 & 28.12 & Black, hot semiarid & Ilango et al. (2002) \\
\hline & $\begin{array}{l}\text { Dichanthium } \\
\text { annulatum }\end{array}$ & 1.98 & 12.56 & 3.33 & 28.12 & Black, hot semiarid & Ilango et al. (2002) \\
\hline & $\begin{array}{l}\text { Vetiveria } \\
\text { zizanioides }\end{array}$ & 2.61 & 18.4 & 3.33 & 28.12 & Black, hot semiarid & Ilango et al. (2002) \\
\hline
\end{tabular}


Table 1. Continued.

\begin{tabular}{|c|c|c|c|c|c|c|c|}
\hline \multirow{2}{*}{$\begin{array}{l}\text { Grazing } \\
\text { Treatment }\end{array}$} & \multicolumn{3}{|c|}{ Open grazing } & \multicolumn{2}{|c|}{ Grazing management } & \multirow[t]{2}{*}{ Soil type and climate } & \multirow[t]{2}{*}{ Source } \\
\hline & & $\begin{array}{r}\text { Soil loss } \\
\left(\mathrm{Mg} \mathrm{ha}^{-1} \mathrm{yr}^{-1}\right)\end{array}$ & $\begin{array}{r}\text { Runoff } \\
(\%)\end{array}$ & $\begin{array}{r}\text { Soil loss } \\
\left(\mathrm{Mg} \mathrm{ha}^{-1} \mathrm{yr}^{-1}\right)\end{array}$ & $\begin{array}{r}\text { Runoff } \\
(\%)\end{array}$ & & \\
\hline & & 2.35 & 27 & 0.85 & 19 & Red, hot subhumid & Hazra and Singh (1986) \\
\hline & & 3.28 & 22 & 0.58 & 11 & Red, hot subhumid & Hazra and Singh (1986) \\
\hline & & - & 24 & - & 13.9 & Alluvial, hot subhumid & Bhatt et al. (2013) \\
\hline & & - & 11.3 & - & 6.6 & Alluvial, hot subhumid & Bhatt et al. (2013) \\
\hline & & 1.52 & 21.6 & 1.52 & 10.2 & Black, hot semiarid & Rao and Reddy (1996) \\
\hline & & 3.26 & 29.34 & 0.84 & 15.35 & Black, hot semiarid & Rao and Reddy (1996) \\
\hline & & & 20.40 & 1.18 & 9.6 & Alluvial, subtropical & Khola (2004) \\
\hline & & & 33.40 & & 19.2 & & Khola (2004) \\
\hline & & & 29.90 & & 22.2 & & Khola (2004) \\
\hline \multicolumn{8}{|l|}{ Combination } \\
\hline \multicolumn{4}{|c|}{ With grass (SWC) } & \multicolumn{2}{|c|}{ Without grass (SWC) } & Soil type and climate & Source \\
\hline & & $\begin{array}{r}\text { Soil loss } \\
\left(\mathrm{Mg} \mathrm{ha}^{-1} \mathrm{yr}^{-1}\right)\end{array}$ & $\begin{array}{r}\text { Runoff } \\
(\%)\end{array}$ & $\begin{array}{r}\text { Soil loss } \\
\left(\mathrm{Mg} \mathrm{ha}^{-1} \mathrm{yr}^{-1}\right)\end{array}$ & $\begin{array}{r}\text { Runoff } \\
(\%)\end{array}$ & & \\
\hline \multirow{12}{*}{\multicolumn{2}{|c|}{$\begin{array}{l}\text { Trenching }+ \text { vegetative } \\
\text { barrier }\end{array}$}} & - & 3.4 & - & 27.6 & Alluvial, subtropical & Khola (2004) \\
\hline & & - & 10.5 & - & 48.5 & Alluvial, subtropical & Khola (2004) \\
\hline & & - & 7.6 & - & 45.5 & & Khola (2004) \\
\hline & & 0.84 & 10.2 & 1.53 & 21.6 & Vertisol, hot semiarid & Rao and Reddy (1996) \\
\hline & & 1.18 & 15.5 & 3.26 & 29.3 & Vertisol, hot semiarid & Rao and Reddy (1996) \\
\hline & & 0.93 & 8.7 & 1.55 & 17.6 & Vertisol, hot semiarid & Ali et al. (2014) \\
\hline & & 0.66 & 4.1 & 1.55 & 17.6 & & Ali et al. (2014) \\
\hline & & 0.05 & 0.4 & 1.55 & 17.6 & Vertisol, hot semiarid & Ali et al. (2014) \\
\hline & & 6.4 & 10.8 & 19 & 17 & Red laterite, hot subhumid & Sahoo and Adhikari (2014) \\
\hline & & 14 & 12.7 & 23.9 & 17 & Red laterite, hot subhumid & Sahoo and Adhikari (2014) \\
\hline & & 9.9 & 13.4 & 19 & 23.5 & Red laterite, hot subhumid & Sahoo and Adhikari (2014) \\
\hline & & 11 & 15.3 & 23.9 & 23.5 & Red laterite, hot subhumid & Sahoo and Adhikari (2014) \\
\hline \multirow{2}{*}{\multicolumn{8}{|c|}{$\begin{array}{l}\text { (b) } \\
<2 \% \text { slope }\end{array}$}} \\
\hline & & & & & & & \\
\hline $\begin{array}{l}\text { Contour grass } \\
\text { barriers }\end{array}$ & $\begin{array}{l}\text { Soil loss } \\
\left(\mathrm{Mg} \mathrm{ha}^{-1}\right)\end{array}$ & $\begin{array}{r}\text { Runoff } \\
(\%)\end{array}$ & $\begin{array}{r}\text { Yield } \\
\left(\mathrm{kg} \mathrm{ha}^{-1}\right)\end{array}$ & Crop & Soil type and climate & Source & \\
\hline \multirow{4}{*}{$\begin{array}{l}\text { Cynodon } \\
\text { dactylon }\end{array}$} & 3.01 & 18 & 1036 & Rice & Red laterite, hot subhumid & Subudhi and Senapati (1996) & \\
\hline & 5.51 & 16.83 & 1748 & Rice & & Subudhi et al. (1998) & \\
\hline & 4.73 & 15.59 & 1759 & Rice & Red laterite, hot subhumid & Subudhi et al. (1998) & \\
\hline & 4.81 & 15.67 & 1519 & Rice & & Subudhi et al. (1998) & \\
\hline \multirow{5}{*}{$\begin{array}{l}\text { Pennisetum } \\
\text { purpureum }\end{array}$} & 2.68 & 17.4 & 1669 & Rice & Red laterite, hot subhumid & Subudhi and Senapati (1996) & \\
\hline & 3.05 & 18.1 & 1562 & Rice & & Subudhi and Senapati (1996) & \\
\hline & 4.4 & 15.32 & 1828 & Rice & Red laterite, hot subhumid & Subudhi et al. (1998) & \\
\hline & 4.42 & 15.01 & 1925 & Rice & & Subudhi et al. (1998) & \\
\hline & 4.41 & 15.17 & 1877 & Rice & & Subudhi et al. (1998) & \\
\hline \multirow{9}{*}{$\begin{array}{l}\text { Vetiveria } \\
\text { zizanioides }\end{array}$} & 2.22 & 16.6 & 2133 & Rice & Red laterite, hot subhumid & Subudhi and Senapati (1996) & \\
\hline & 4.23 & 14.83 & 2042 & Rice & & Subudhi et al. (1998) & \\
\hline & 4.02 & 14.05 & 1976 & Rice & Red laterite, hot subhumid & Subudhi et al. (1998) & \\
\hline & 3.96 & 13.88 & 2214 & Rice & & Subudhi et al. (1998) & \\
\hline & 7.1 & 34.63 & 2000 & Maize & Red laterite, hot subhumid & Senapati and Sharma (2007) & \\
\hline & 6.89 & 31.59 & 2022 & Maize & & Senapati and Sharma (2007) & \\
\hline & 6.48 & 28.31 & 2053 & Maize & & Senapati and Sharma (2007) & \\
\hline & 1.14 & 16.2 & 1377 & Sorghum & Black soil, hot subhumid & Prasad et al. (2005) & \\
\hline & 0.73 & 13.6 & 699 & Sorghum & & Prasad et al. (2005) & \\
\hline \multirow{4}{*}{$\begin{array}{l}\text { Eulaliopsis } \\
\text { binata }\end{array}$} & 2.37 & 17.5 & 1436 & Rice & Red laterite, hot subhumid & Subudhi and Senapati (1996) & \\
\hline & 4.82 & 15.87 & 1933 & Rice & & Subudhi et al. (1998) & \\
\hline & 5.5 & 16.32 & 1812 & Rice & & Subudhi et al. (1998) & \\
\hline & 5.54 & 16.2 & 1769 & Rice & & Subudhi et al. (1998) & \\
\hline $\begin{array}{l}\text { Cymbopogon } \\
\text { martinii }\end{array}$ & 2.57 & 17.7 & 1911 & Rice & Red laterite, hot subhumid & Subudhi and Senapati (1996) & \\
\hline \multirow{7}{*}{$\begin{array}{l}\text { Dichanthium } \\
\text { annulatum }\end{array}$} & 1.05 & 15.5 & 1364 & Sorghum & Black soil, hot semiarid & Prasad et al. (2005) & \\
\hline & 0.69 & 13.7 & 697 & Sorghum & & Prasad et al. (2005) & \\
\hline & 0.18 & 7.1 & 808 & Sunflower & Inceptisol, black subhumid & Bhanavase et al. (2007) & \\
\hline & 0.85 & 40 & - & & & Bhanavase et al. (2007) & \\
\hline & 0.26 & 12.2 & - & & Inceptisol, black subhumid & Bhanavase et al. (2007) & \\
\hline & 0.3 & 12.5 & - & & & Bhanavase et al. (2007) & \\
\hline & 0.52 & 28.14 & - & & & Bhanavase et al. (2007) & \\
\hline
\end{tabular}


Table 1. Continued.

\begin{tabular}{|c|c|c|c|c|c|c|}
\hline $\begin{array}{l}\text { (b) } \\
<2 \% \text { slope }\end{array}$ & & & & & & \\
\hline $\begin{array}{l}\text { Contour grass } \\
\text { barriers }\end{array}$ & $\begin{array}{r}\text { Soil loss } \\
\left(\mathrm{Mg} \mathrm{ha}^{-1}\right)\end{array}$ & $\begin{array}{r}\text { Runoff } \\
(\%)\end{array}$ & $\begin{array}{r}\text { Yield } \\
\left(\mathrm{kg} \mathrm{ha}^{-1}\right)\end{array}$ & Crop & Soil type and climate & Source \\
\hline \multirow{7}{*}{$\begin{array}{l}\text { Cenchrus } \\
\text { ciliaris }\end{array}$} & 0.14 & 6.5 & 867 & Sunflower & \multirow[t]{2}{*}{ Inceptisol, black subhumid } & Bhanavase et al. (2007) \\
\hline & 0.74 & 34.8 & - & & & Bhanavase et al. (2007) \\
\hline & 0.21 & 11.6 & - & & \multirow[t]{2}{*}{ Inceptisol, black subhumid } & Bhanavase et al. (2007) \\
\hline & 0.22 & 11 & - & & & Bhanavase et al. (2007) \\
\hline & 0.46 & 24.12 & - & & \multirow[t]{3}{*}{ Black soil, hot semiarid } & Bhanavase et al. (2007) \\
\hline & 1.01 & 15.8 & 1359 & Sorghum & & Prasad et al. (2005) \\
\hline & 0.77 & 13.9 & 697 & Sorghum & & Prasad et al. (2005) \\
\hline \multirow{2}{*}{$\begin{array}{l}\text { Saccharum } \\
\text { munja }\end{array}$} & 0.86 & 16.3 & 1355 & Sorghum & \multirow[t]{2}{*}{ Black soil, hot semiarid } & Prasad et al. (2005) \\
\hline & 0.7 & 13.4 & 674 & Sorghum & & Prasad et al. (2005) \\
\hline \multirow{7}{*}{$\begin{array}{l}\text { Stylosanthes } \\
\text { hamata }\end{array}$} & 8.92 & 33.52 & 1789 & Maize & \multirow[t]{2}{*}{ Red laterite, hot subhumid } & Senapati and Sharma (2007) \\
\hline & 8.21 & 33.21 & 1766 & Maize & & Senapati and Sharma (2007) \\
\hline & 8.13 & 34.41 & 1733 & Maize & \multirow[t]{5}{*}{ Red laterite, hot subhumid } & Senapati and Sharma (2007) \\
\hline & 5.81 & 16.87 & 1777 & Rice & & Subudhi et al. (1998) \\
\hline & 5.85 & 16.92 & 1775 & Rice & & Subudhi et al. (1998) \\
\hline & 5.61 & 16.63 & 1803 & Rice & & Subudhi et al. (1998) \\
\hline & 2.8 & 18.2 & 1280 & Rice & & Subudhi and Senapati (1996) \\
\hline \multirow{3}{*}{$\begin{array}{l}\text { Pennisetum } \\
\text { pedicellatum }\end{array}$} & 8.01 & 34.01 & 2011 & Maize & \multirow[t]{3}{*}{ Red laterite, hot subhumid } & Senapati and Sharma (2007) \\
\hline & 7.01 & 30.98 & 1990 & Maize & & Senapati and Sharma (2007) \\
\hline & 6.97 & 31.64 & 1969 & Maize & & Senapati and Sharma (2007) \\
\hline \multirow[t]{14}{*}{ Control } & 3.47 & 21.4 & 1236 & Rice & \multirow[t]{2}{*}{ Red laterite, hot subhumid } & Subudhi and Senapati (1996) \\
\hline & 10.39 & 19.94 & 1332 & Rice & & Subudhi et al. (1998) \\
\hline & 7.54 & 19.02 & 1330 & Rice & \multirow[t]{3}{*}{ Red laterite, hot subhumid } & Subudhi et al. (1998) \\
\hline & 7.24 & 19.18 & 1508 & Rice & & Subudhi et al. (1998) \\
\hline & 8.45 & 40.18 & 1720 & Maize & & Senapati and Sharma (2007) \\
\hline & 9.22 & 42.32 & 1790 & Maize & \multirow[t]{2}{*}{ Red laterite, hot subhumid } & Senapati and Sharma (2007) \\
\hline & 9.02 & 42.6 & 1717 & Maize & & Senapati and Sharma (2007) \\
\hline & 1.89 & 22 & 1140 & Sorghum & \multirow{2}{*}{ Black soil, hot subhumid } & Prasad et al. (2005) \\
\hline & 1.45 & 20.2 & 562 & Sorghum & & Prasad et al. (2005) \\
\hline & 0.22 & 10.12 & 618 & Sunflower & \multirow[t]{2}{*}{ Inceptisol, black subhumid } & Bhanavase et al. (2007) \\
\hline & 1.15 & 53 & - & & & Bhanavase et al. (2007) \\
\hline & 0.4 & 15.2 & - & & \multirow[t]{3}{*}{ Inceptisol, black subhumid } & Bhanavase et al. (2007) \\
\hline & 0.5 & 16.2 & - & & & Bhanavase et al. (2007) \\
\hline & 0.8 & 40.2 & - & & & Bhanavase et al. (2007) \\
\hline \multicolumn{7}{|l|}{$2-4 \%$ slope } \\
\hline \multirow{11}{*}{$\begin{array}{l}\text { Vetiveria } \\
\text { zizanioides }\end{array}$} & 2.54 & 16.27 & 1075 & Black gram & \multirow[t]{2}{*}{ Red laterite, hot subhumid } & Mishra and Sahu (2001) \\
\hline & 1.78 & 18.45 & 803 & Black gram & & Mishra and Sahu (2001) \\
\hline & 3.5 & 27.4 & 5.9 & Sorghum & Alluvial soil, subhumid & Chand and Bhan (2000) \\
\hline & 7.2 & 33 & 1900 & Maize & & Bhardwaj and Sindhwal (2007) \\
\hline & 9.8 & 43 & 2389 & Maize & Alluvial, subtropical & Bhardwaj and Sindhwal (2007) \\
\hline & 8.6 & 42 & 2063 & Maize & Alluvial, subtropical & Bhardwaj and Sindhwal (2007) \\
\hline & 6.9 & 40 & 2042 & Maize & Alluvial, subtropical & Bhardwaj and Sindhwal (2007) \\
\hline & 2.9 & 22 & 3124 & Maize & & Bhardwaj and Sindhwal (2007) \\
\hline & 5 & 30 & 3144 & Maize & & Bhardwaj and Sindhwal (2007) \\
\hline & 5.5 & 27 & 2278 & Maize & & Bhardwaj and Sindhwal (2007) \\
\hline & 6.72 & 35.1 & 2444 & Maize & & Bhardwaj and Sindhwal (2007) \\
\hline Pennisetum & 3.08 & 16.5 & 1002 & Black gram & Red laterite, hot subhumid & Mishra and Sahu (2001) \\
\hline purpureum & 2.96 & 18.88 & 624 & Black gram & & Mishra and Sahu (2001) \\
\hline
\end{tabular}


Table 1. Continued.

\begin{tabular}{|c|c|c|c|c|c|c|}
\hline $\begin{array}{l}\text { Cultivated } \\
\text { fallow }\end{array}$ & 7.87 & 23.5 & & Rice & Red laterite, hot subhumid & Subudhi and Senapati (1996) \\
\hline \multirow{10}{*}{$\begin{array}{l}\text { Eulaliopsis } \\
\text { binata }\end{array}$} & 3.15 & 18.24 & 836 & Black gram & \multirow[t]{2}{*}{ Red laterite, hot subhumid } & Mishra and Sahu (2001) \\
\hline & 2.75 & 20.51 & 618 & Black gram & & Mishra and Sahu (2001) \\
\hline & 7.9 & 34 & 1869 & Maize & \multirow{8}{*}{$\begin{array}{l}\text { Alluvial, subtropical } \\
\text { Alluvial, subtropical } \\
\text { Alluvial, subtropical } \\
\text { Alluvial, subtropical }\end{array}$} & Bhardwaj and Sindhwal (2007) \\
\hline & 10.6 & 46 & 2333 & Maize & & Bhardwaj and Sindhwal (2007) \\
\hline & 12.4 & 49 & 1833 & Maize & & Bhardwaj and Sindhwal (2007) \\
\hline & 8.3 & 42 & 1961 & Maize & & Bhardwaj and Sindhwal (2007) \\
\hline & 3.6 & 25 & 2941 & Maize & & Bhardwaj and Sindhwal (2007) \\
\hline & 7.3 & 31 & 2839 & Maize & & Bhardwaj and Sindhwal (2007) \\
\hline & 7.3 & 32 & 2028 & Maize & & Bhardwaj and Sindhwal (2007) \\
\hline & 8.34 & 37.9 & 2296 & Maize & & Bhardwaj and Sindhwal (2007) \\
\hline \multirow{3}{*}{$\begin{array}{l}\text { Heteropogon } \\
\text { contortus }\end{array}$} & 0.08 & 5.5 & 523 & Sorghum & \multirow[t]{3}{*}{ Red soil, hot subhumid } & Narayan et al. (2014) \\
\hline & 0.6 & 15.9 & - & & & Narayan et al. (2014) \\
\hline & 0.2 & 4.1 & - & & & Narayan et al. (2014) \\
\hline \multirow{4}{*}{$\begin{array}{l}\text { Cenchrus } \\
\text { ciliaris }\end{array}$} & 0.9 & 8.37 & 509 & Sorghum & \multirow{3}{*}{$\begin{array}{l}\text { Red soil, hot subhumid red } \\
\text { soil, hot subhumid }\end{array}$} & Narayan et al. (2014) \\
\hline & 0.82 & 19.4 & - & & & Narayan et al. (2014) \\
\hline & 0.3 & 6.84 & - & & & Narayan et al. (2014) \\
\hline & 4 & 30.2 & 7.2 & Sorghum & Alluvial soil, subhumid & Chand and Bhan (2000) \\
\hline \multirow{8}{*}{$\begin{array}{l}\text { Panicum } \\
\text { antidotale }\end{array}$} & 6.12 & 33.3 & 2460 & Maize & \multirow[t]{8}{*}{ Alluvial, subtropical } & Bhardwaj and Sindhwal (2007) \\
\hline & 5.8 & 29 & 1911 & Maize & & Bhardwaj and Sindhwal (2007) \\
\hline & 8.1 & 41 & 2528 & Maize & & Bhardwaj and Sindhwal (2007) \\
\hline & 7.6 & 38 & 2073 & Maize & & Bhardwaj and Sindhwal (2007) \\
\hline & 6.2 & 39 & 2059 & Maize & & Bhardwaj and Sindhwal (2007) \\
\hline & 2.9 & 23 & 3109 & Maize & & Bhardwaj and Sindhwal (2007) \\
\hline & 6.1 & 31 & 3089 & Maize & & Bhardwaj and Sindhwal (2007) \\
\hline & 6.8 & 28 & 2138 & Maize & & Bhardwaj and Sindhwal (2007) \\
\hline \multirow[t]{7}{*}{ Control } & 3.42 & 17.35 & 965 & Black gram & \multirow[t]{2}{*}{ Red laterite, hot subhumid } & Mishra and Sahu (2001) \\
\hline & 3.27 & 20.75 & 603 & Black gram & & Mishra and Sahu (2001) \\
\hline & 7.5 & 46.5 & 5.3 & Sorghum & \multirow[t]{2}{*}{ Alluvial soil, subhumid } & Chand and Bhan (2000) \\
\hline & 46.28 & 18.04 & - & Maize & & Bhardwaj and Sindhwal (2007) \\
\hline & 0.41 & 19.8 & 480 & Sorghum & \multirow{3}{*}{$\begin{array}{l}\text { Alluvial, subtropical } \\
\text { Red soil, hot subhumid }\end{array}$} & Narayan et al. (2014) \\
\hline & 1.4 & 29.7 & - & & & \\
\hline & 1 & 13.7 & - & & & \\
\hline \multicolumn{7}{|l|}{$>4 \%$ slope } \\
\hline \multirow{3}{*}{$\begin{array}{l}\text { Thysanolaena } \\
\text { maxima }\end{array}$} & 6.92 & 13.85 & 891 & Finger millet & \multirow[t]{3}{*}{ Red laterite, hot subhumid } & \multirow[t]{3}{*}{ Sudhishri et al. (2008) } \\
\hline & 6.02 & 13 & 1105 & & & \\
\hline & 7.16 & 14.06 & 1045 & & & \\
\hline \multirow{4}{*}{$\begin{array}{l}\text { Vetiver } \\
\text { zizanioides }\end{array}$} & 4.22 & 8.79 & 1092 & Finger millet & \multirow[t]{4}{*}{ Red laterite, hot subhumid } & \multirow[t]{4}{*}{ Sudhishri et al. (2008) } \\
\hline & 3.85 & 7.85 & 1226 & & & \\
\hline & 4.06 & 9.88 & 1346 & & & \\
\hline & 9.87 & 40.52 & 2180 & & & \\
\hline \multirow{2}{*}{$\begin{array}{l}\text { Saccharum } \\
\text { munja }\end{array}$} & 3.87 & 18.93 & 963 & Black gram & Red laterite, hot subhumid & Mishra and Sahu (2001) \\
\hline & 3.07 & 21.04 & 603 & Black gram & & Mishra and Sahu (2001) \\
\hline Saccharum & 4.49 & 9.36 & 1045 & Finger millet & Red laterite, hot subhumid & Sudhishri et al. (2008) \\
\hline munja & 4.02 & 8.25 & 1226 & & & \\
\hline & 4.65 & 10.83 & 1427 & & & \\
\hline $\begin{array}{l}\text { Cynodon } \\
\text { dactylon }\end{array}$ & 2.1 & 27.1 & 4355 & & Alluvial (Entisols) subhumid tropical & Narain et al. (1994) \\
\hline Dichanthium & 1.02 & 21.2 & 6805 & & Alluvial (Entisols) subhumid tropical & Narain et al. (1994) \\
\hline annulatum & 0.23 & 1.9 & & & & \\
\hline
\end{tabular}


Table 1. Continued.

\begin{tabular}{lrrrlll}
\hline $\begin{array}{l}\text { Cultivated } \\
\text { fallow }\end{array}$ & 7.87 & 23.5 & & Rice & Red laterite, hot subhumid & Subudhi and Senapati (1996) \\
\hline $\begin{array}{l}\text { Eulaliopsis } \\
\text { binata }\end{array}$ & 0.29 & 5.2 & 16290 & & Alluvial (Entisols) subhumid tropical & Narain et al. (1994) \\
\hline $\begin{array}{l}\text { Chrysopogon } \\
\text { fulvus }\end{array}$ & 0.3 & 2.5 & 19170 & & Alluvial (Entisols) subhumid tropical & Narain et al. (1994) \\
\hline Control & 83.04 & 32.6 & - & Finger millet & Alluvial (Entisols) subhumid tropical & Narain et al. (1994) \\
& 18.45 & 16.2 & - & & & Narain et al. (1994) \\
& 92.42 & 71.1 & - & & Red laterite, hot subhumid & Sudhishri et al. (2008) \\
& 13.9 & 26.02 & 607 & & & Sudhishri et al. (2008) \\
& 13.7 & 24.84 & 676 & & & Sudhishri et al. (2008) \\
\hline
\end{tabular}

Table 2. Various attributes and normalized scores used for calculating CPI for different vegetative barriers.

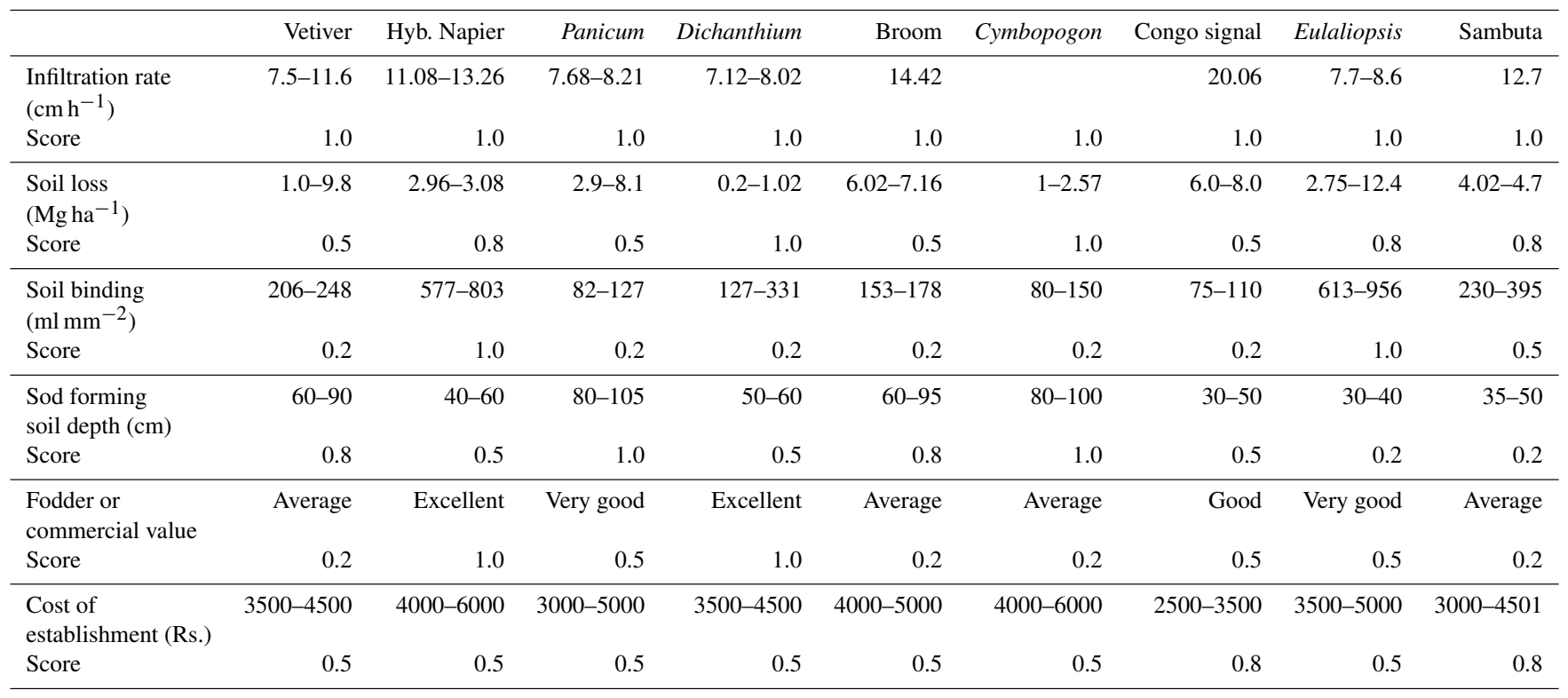

reference sites were adjacent to the grass-treated field/plots within the same landscape and similar slope. Therefore, we excluded studies where the reference site was either missing or was away from the study site. The conservation use efficiency (CUE) was calculated by the following formula (Khola and Sastry, 2005):

$\mathrm{CUE}=$ $\frac{\text { Water/soil runoff rate before conservation measure }- \text { Water/soil runoff rate after conservationn measure }}{\text { Water/soil runoff rate before conservation measure }} \times 100$.

Data were analyzed using SPSS (version 17). The analysis of variance (ANOVA) was conducted to test the significant difference between different treatments. Initially, a $t$ test was conducted to test whether the impacts of two treatments (without grass and with grass) were significantly different. Protected least significant difference (LSD) at $P=0.05$ was used to separate the means for all the three different categories of data (Fisher, 1935). A separate $t$ test was also used for different slope classes to evaluate the performance of CGBs on the reduction of soil and water loss and enhancing crop yield.

Relative performance of different grasses used as CGB was evaluated by using a comprehensive performance index (CPI). The following formula was used to compute CPI values of different grasses (Sudhishri et al., 2008):

$\mathrm{CPI}=\sum_{i=1}^{n} W_{i} R_{i}$,

where CPI is comprehensive performance index of the grass species, $W_{i}$ is weighting of the $i$ th parameter, and $R_{i}$ is rating (scoring) of the $i$ th parameter based on its observed value. A total of six attributes - namely infiltration rate (IR), soil loss, root binding capacity, maximum sod forming depth, fodder/commercial value and cost of establishment (Table 2) - were used for computing CPI. 
Additionally, relative reversibility of erosion/water loss and relative yield gained due to adoption of CGBs were computed by using the following formulas:

Relative reversibility of erosion/water loss:

$\Delta$ Erosion $/ \Delta$ Runoff $=$

Erosion/water loss withoutCGB - Erosion/water loss with CGB Mean erosion/water loss

Relative yield gain:

$\Delta$ Yield gain $=$

$\frac{\text { Mean yield with CGB }- \text { Mean yield without CGB }}{\text { Mean yield }} \times 100$.

\section{Results and discussion}

\subsection{Contour grass barrier (CGB)}

India is home to about 1225 species of grasses, the majority of which grow well in tropical and subtropical regions (Prakash et al., 1999). These grasses can be used as live bunds in arresting soil erosion. The efficacy of CGBs in increasing the opportunity time for infiltration and consequent profile recharge has also been reported by other researchers (Sharma and Bhatt, 1996; Prakash et al., 1999). In this metaanalysis, based on 25 observations, we quantified the general potential of vegetative barriers to reduce runoff and soil loss (Table 3 ). The overall result of the meta-analysis showed that infiltration capacity increased approximately 2-fold after planting grasses across the slopes in agricultural fields (95\% confidence level). However, it is interesting to note that the mean runoff values were statistically insignificant in the case of combined treatment of grasses along with structural measures. This may be due to very high standard deviation (SD) values obtained for vegetative barrier. These higher values indicate considerable heterogeneity in the observation which needs to be verified. Although $70 \%$ of data showed similar variation, a few higher values were not in expected lines, which might have caused this uncertainty. In the case of the Doon Valley region, through comparing the impacts on soil wetting pattern, infiltration rate and sorptivity, it was observed that Chrysopogon fulvus was the most promising potential grass species. However, for this region Panicum maximum was identified as the most effective grass barrier with maize. Therefore, more research is required with Chrysopogon fulvus because the rooting pattern, soil wetting, infiltration rate and other properties of this grass show great potential to be used as a contour grass barrier in this region (Mandal and Jayaprakash, 2009). It was identified by Bhardwaj and Sindhwal (2007) that Saccharum munja and Eulaliopsis binata are the two most effective grasses for the Shivalik region of Punjab and Haryana, while hybrid Napier grass and Panicum maximum are very effective in humid tropical regions of the lower Himalayas.
Runoff and soil loss values in CGB plots were lower than the control plots. The data show that runoff varies between 11.26 and $62.60 \%$ with a mean value of $37.71 \%$ and soil loss varies between 0.53 and $30.90 \mathrm{Mg} \mathrm{ha}^{-1} \mathrm{yr}^{-1}$ with a mean value of $9.56 \mathrm{Mg} \mathrm{ha}^{-1} \mathrm{yr}^{-1}$ in control treatments (Table 3). With CGB, the runoff data varies between 5.87 and $44.10 \%$ with a mean value of $20.93 \%$ and soil loss varies between 0.50 and $18.70 \mathrm{Mg} \mathrm{ha}^{-1} \mathrm{yr}^{-1}$ with a mean value of $3.93 \mathrm{Mg} \mathrm{ha}^{-1} \mathrm{yr}^{-1}$. The study revealed that, on average, the overland flow reduced by $45 \%$ compared to control. CGB facilitated the appearance of backed-up water above the filter strips, which resulted in sedimentation and substantial reduction in soil loss. The analysis of the data indicated that as the rain proceeded, overland flow moved down slope into the grass hedges and water backed-up behind them, giving more opportunity time for the water to infiltrate the soil. Experiments conducted by Becker (2001) reported reduced soil erosion by parallel strips of stiff-stemmed grass planted along the contour lines. In addition, the amount of transported soil reduced by $59 \%$ in the case of grass barriers than that of the control. A substantial reduction in runoff from $37.71 \%$ in control to $20.93 \%$ in CGB was observed. Vegetative barriers reduced the soil loss from 9.0 to $3.0 \mathrm{Mg} \mathrm{ha}^{-1} \mathrm{yr}^{-1}$. The CUE of vegetative barrier was found to be 44.56 and $59.04 \%$, for runoff and soil loss, respectively. These findings are in conformity with the results reported by Gilley et al. (2000), who showed that grass hedges have the potential to reduce runoff by $52 \%$ and soil loss by $53 \%$ under no-till conditions. Globally, most researchers in tropical region have used vetiver grass (Vetiveria zizanioides), eastern gamagrass (Tripsacum dactyloides) due to their special characteristics with stiff, erect and coarse stems (Rachman et al., 2004a, b, 2005; Janushaj, 2005). Such species are perennial in nature and thus give good protective cover throughout the year in warm humid topics.

In terms of soil loss, the vegetative barrier of Panicum maximum showed promising performance with an average rate of soil loss between 2.74 and $7.93 \mathrm{Mg} \mathrm{ha}^{-1} \mathrm{yr}^{-1}$ in northwestern Himalayan region, which indicated that soil loss can be effectively brought below the tolerance limit by adopting such SCMs (Mandal et al., 2006). Considering the advantages of contour grass strips compared to mechanical measures, due to their lower cost and minimum removal of the fertile topsoil, many organizations are promoting this practice as an effective measure to reduce erosion (ASAE, 1981; Hudson, 1981; Mulugeta, 1988; Turkelboom et al., 1994). Moreover, CGB is comparatively simple and easy to establish (Grunder, 1988), while mechanical measures are too expensive, difficult to maintain in the long run (Rodriguez, 1997) and are time consuming (Tripathi and Singh, 1993). Additional advantages with regard to establishment and stabilization of the grass strip are that it needs very little attention to form a terrace, while mechanical measures need regular maintenance to maintain their effectiveness (Welle et al., 2006). 
Table 3. Impact of grasses in arresting soil loss and runoff.

\begin{tabular}{|c|c|c|c|}
\hline Treatment & $\begin{array}{r}\text { Runoff } \\
(\%)\end{array}$ & $\begin{array}{r}\text { Soil loss } \\
\left(\mathrm{Mg} \mathrm{ha}^{-1} \mathrm{yr}^{-1}\right)\end{array}$ & $\begin{array}{r}\text { Number of } \\
\text { samples }(n)\end{array}$ \\
\hline \multicolumn{4}{|l|}{ Vegetative barrier } \\
\hline $\begin{array}{l}\text { Control } \\
\text { (without grass) }\end{array}$ & $\begin{array}{r}11.26-62.40 \\
(37.71 \pm 18.12)^{\mathrm{a}}\end{array}$ & $\begin{array}{r}0.53-30.90 \\
(9.56 \pm 8.79)^{\mathrm{a}}\end{array}$ & 25 \\
\hline With grass & $\begin{array}{r}5.87-44.10 \\
(20.93 \pm 10.76)^{\mathrm{b}}\end{array}$ & $\begin{array}{r}0.5-18.7 \\
(3.93 \pm 5.03)^{b}\end{array}$ & 25 \\
\hline Conservation use efficiency (CUE) & 44.56 & 59.04 & 25 \\
\hline \multicolumn{4}{|c|}{ Along with structural conservation measures } \\
\hline Control & $\begin{array}{r}17.0-48.5 \\
(25.53 \pm 10.88)^{\mathrm{a}}\end{array}$ & $\begin{array}{r}1.53-3.26 \\
(1.88 \pm 0.77)^{\mathrm{a}}\end{array}$ & 17 \\
\hline Combination & $\begin{array}{r}0.40-15.30 \\
(9.37 \pm 4.76)^{\mathrm{a}}\end{array}$ & $\begin{array}{r}0.05-1.18 \\
(0.73 \pm 0.42)^{\mathrm{a}}\end{array}$ & 17 \\
\hline Conservation use efficiency (CUE) & 62.93 & 60.96 & 17 \\
\hline \multicolumn{4}{|l|}{ Grazing management } \\
\hline Control (grazed) & $\begin{array}{r}11.30-33.4 \\
(24.33 \pm 6.55)^{\mathrm{a}}\end{array}$ & $\begin{array}{r}1.52-3.28 \\
(2.58 \pm 0.73)^{\mathrm{a}}\end{array}$ & 12 \\
\hline Management & $\begin{array}{r}6.60-22.2 \\
(14.12 \pm 5.23)^{b}\end{array}$ & $\begin{array}{r}0.58-1.3 \\
(0.95 \pm 0.29)^{\mathrm{b}}\end{array}$ & 12 \\
\hline Conservation use efficiency (CUE) & 42.01 & 63.18 & 12 \\
\hline
\end{tabular}

Values in the parentheses are mean $\pm \mathrm{SD}$. Different letters in the same column are significantly different at $P<0.05$.

Table 4. Site-specific suitable grasses for contour grass barrier (CGBs).

\begin{tabular}{|c|c|c|c|}
\hline Site no. & State & Crop & Barrier \\
\hline 1 & Andhra Pradesh & Sorghum/castor & Cenchrus ciliaris (buffel grass) \\
\hline \multirow[t]{2}{*}{2} & Haryana & Urd & Mixed barrier of Vetiveria zizanioides (vetiver) plus \\
\hline & & Bajra and wheat & Eulaliopsis binata (sabai grass) \\
\hline \multirow[t]{3}{*}{3} & Karnataka & Groundnut & Vetiveria zizanioides (Vetiver) on contour \\
\hline & & Finger millet & Combination of graded bund and Vetiveria zizanioides (vetiver) \\
\hline & & Sorghum & Compartmental bunding with Vetiveria zizanioides (vetiver) \\
\hline 4 & Madhya Pradesh & Soyabean & Cymbopogon martinii (lemon grass/palmarosa) \\
\hline 5 & Maharashtra & Sorghum, cotton & Vetiveria zizanioides (vetiver) \\
\hline 6 & Orissa & Paddy & Vetiveria zizanioides (vetiver), Cynodon dactylon (Bermuda grass) \\
\hline & & Cowpea (green pod) & \\
\hline 7 & Punjab & Maize & Saccharum spp. \\
\hline 8 & Tamil Nadu & Potato & Pennisetum purpureum (Napier/elephant grass) \\
\hline 9 & Uttarakhand & Corn & Panicum maximum (Guinea grass) \\
\hline
\end{tabular}

A study by Shrimali (2000) revealed that Panicum maximum provided $56 \%$ of coverage after 3 years of planting. The coverage increased progressively from $23 \%$ in the first year to $56 \%$ in the third year. Similarly, vetiver coverage increased from $29 \%$ in the first year to $75 \%$ in the third year (Shrimali, 2000). Vetiver grass distinctively showed the highest reduction in annual runoff and soil loss. This was attributed to the fact that the erect and rather stiff leaves and stems of vetiver grass retarded more runoff flow and acted as a filter to retain more sediment. A similar performance level of vegetative barrier was also reported by Rao et al. (1991) and Laing and Rupenthal (1991). This is also in conformity with the results of Patil et al. (1995), who recorded $41.4 \%$ lower runoff for vetiver over control. Similar results had been obtained by Tangtumniyom et al. (1996) for a cassava crop on a $5 \%$ slope where vetiver was used as vegetative barrier. The effect produced by Cenchrus ciliaris planted at $10 \mathrm{~m}$ spacing was also comparable to that of vetiver at $10 \mathrm{~m}$, which recorded a mean annual soil loss of $3.39 \mathrm{Mg} \mathrm{ha}^{-1}$ (Jagannathan et al., 2000).

The conservation efficiency of CGB varies with grass types and site conditions in different regions. However, Pen- 
nisetum purpureum, Panicum maximum and Eulaliopsis binata were very effective for the lower Himalayan and Shivalik regions. Results from different studies across the country showed that, due to the large amount of green phytomass, profuse tillering and dense rhizomatous network of roots, runoff and soil losses were significantly reduced with a barrier of Pennisetum purpureum. For different regions of India, including Andhra Pradesh, Haryana, Karnataka, Madhya Pradesh, Maharashtra, Orissa, Punjab, Tamil Nadu and Uttarakhand, suitable grasses for CGB are given in Table 4. In situations where fodder requirements are high, Pennisetum purpureum mounted as a barrier would be beneficial, while in those areas where soil conservation is of utmost importance, Eulaliopsis binata or aromatic grasses such as palmarosa (Cymbopogon martinii) or vetiver (Vetiveria zizanioides) grass would be a reasonable choice.

Analysis of variance through $t$ tests of soil loss, runoff and yields of crops indicated that loss of water was significantly lower in CGB-treated sites in $<2 \%$ slopes (Table 5). The water loss provided by CGBs compared to control was $16 \%$ vs. $27 \%$ for the $<2 \%$ slope. However, the similar trend was not observed in the $2-4 \%$ slope range. Interestingly, the soil loss was significantly lower in CGB-treated sites in higher slopes (2-4 and $>4 \%$ slopes).

Variations in soil erosion amounts paralleled to some extent those of runoff in all the slope classes except in the lower slope range (Table 5). The protective actions of various CGBs are very clearly shown by the soil loss values, which show that between 141 and $107 \%$ reversibility in soil loss can be achieved through adoption of CGB. The relative reversibility of water loss provided by CGBs compared to control was $52.6 \%$ for the $<2 \%$ slope and $55.5 \%$ for $>4 \%$ slopes. Favorable soil conditions created by CGBs resulted in an increase of yield in all slope ranges. The significantly higher yield in CGB treated sites may be due to either better moisture regime or higher nutrients or may be depending on both the retention of runoff and deposition of fertile sediment by the CGBs. The relative yield gained by CGBs varied between 44 and $53 \%$, with highest value in the $2-4 \%$ slope.

A clear picture about the relative merit of CGBs was determined through development of a CPI for different grasses (Table 6). Hybrid Napier grass (Pennisetum purpureum) seems to have the most desirable attributes for soil and water conservation, with the highest CPI value of 0.81 . On the other hand, Saccharum munja had fairly good merit (0.79) in conserving soil and water and has both fodder and commercial value. Similarly, Dichanthium annulatum, with a CPI value of 0.77 , has an edge over broom grass (0.72). However, from the point of view of farmers' adaptation, both Saccharum munja (0.79) and Thysanolaena maxima (0.72) grass are the most preferred species, especially in shifting cultivation area of the Eastern Ghats and northeastern hilly region of India.

\subsection{Complementary role of grasses with physical soil structures}

Grasses, shrubs and tree barriers in combination with structural measures (bioengineering measures) are known to be beneficial for soil and water conservation and have many relative advantages over structural interventions. Reinforcement by live roots which bind soil particles and underground decomposed biomass provides stability to aggregated soil. Plant detritus on the soil surface acts as a cushion for dissipating kinetic energy of rain drops. This aboveground biomass upon its subsequent decomposition also adds to the soil humus and increases infiltration, soil water-holding capacity and stability of aggregates (Prakash et al., 1999).

The data from Table 3 show that the use of grasses led to a significant decrease in runoff from $25.53 \%$ in control to $9.37 \%$ with structural conservation measures. Soil loss also has a significant decrease from $1.88 \mathrm{Mg} \mathrm{ha}^{-1} \mathrm{yr}^{-1}$ in control to $0.73 \mathrm{Mg} \mathrm{ha}^{-1} \mathrm{yr}^{-1}$ in structural conservation measures (Table 2). The runoff varies between 17.00 and $48.50 \%$ with a mean value of $25.53 \%$ and soil loss varies between 1.53 and $3.26 \mathrm{Mg} \mathrm{ha}^{-1} \mathrm{yr}^{-1}$ with a mean value of $1.88 \mathrm{Mg} \mathrm{ha}^{-1} \mathrm{yr}^{-1}$ in control. The runoff varies between 0.40 and $15.30 \%$ with a mean value of $9.37 \%$ in combined treatment (grass along with structural measures). The data revealed that the impact of grasses was more pronounced along with soil and water conservation measures in minimizing the losses of soil and water. In addition, the complimentary action shows water saving by $63 \%$ and soil saving by $61 \%$.

Earthen bund and earthen bund with broom grass was found to be more effective in soil moisture conservation at 4 and $8 \%$ slope as compared to other treatments (Fig. 1). The study conducted on Pennisetum and Arundinella barriers in combination with soil conservation measures revealed a substantial reduction (65-88 and $15-38 \%$, respectively) in overland flow compared to the control plots (Huang et al., 2010).

\subsection{Management of grazing lands}

In India about 12.0 Mha of area is represented by permanent pasture and grasslands, majority of which is confined to the tropical areas (Roy and Singh, 2013). Since this pasture land and grasslands are severely affected by soil erosion, special attention should be given to their management to reverse the process of degradation. Our synthesis of the meta-analysis revealed that, by managing the grassland with cut and carry system, rotational grazing and control grazing can greatly reduce the water and soil loss and helps in the reversing the land degradation process. Similar phenomena have been reported by Misri (2003) and Pathak and Dagar (2015), especially for the lower Himalayan and Shivalik grassland, where severe biotic pressure is imposed by both sedentary and migratory grazers. The grazing intensity in the country is as 
Table 5. Relative merits of contour grass barrier (CGBs) in different land slopes.

\begin{tabular}{|c|c|c|c|c|}
\hline Treatment & $\begin{array}{r}\text { Runoff } \\
(\%)\end{array}$ & $\begin{array}{r}\text { Soil loss } \\
\left(\mathrm{Mg} \mathrm{ha}^{-1} \mathrm{yr}^{-1}\right)\end{array}$ & Yield & $\begin{array}{r}\text { Number of } \\
\text { samples }(n)\end{array}$ \\
\hline \multicolumn{5}{|l|}{$<2 \%$ slope } \\
\hline \multirow{2}{*}{ Control (without grass) } & $10.12-42.60$ & $0.22-10.39$ & $546-1717$ & 12 \\
\hline & $(27.10 \pm 13.58)^{\mathrm{a}}$ & $(5.03 \pm 3.92)^{\mathrm{a}}$ & $(1179 \pm 475.32)^{\mathrm{a}}$ & \\
\hline \multirow[t]{2}{*}{ With grass } & $13.88-16.92$ & $3.82-5.85$ & $1519-2214$ & 12 \\
\hline & $(15.81 \pm 1.06)^{\mathrm{b}}$ & $(5.03 \pm 0.69)^{\mathrm{a}}$ & $(1843 \pm 176.09)^{b}$ & \\
\hline Relative reversibility & $52.64 \%$ & Insignificant & $44 \%$ & \\
\hline \multicolumn{5}{|l|}{$2-4 \%$ slope } \\
\hline \multirow[t]{2}{*}{ Control (without grass) } & $13.20-71.10$ & $0.41-92.42$ & $345-965$ & 12 \\
\hline & $(28.36 \pm 15.36)^{\mathrm{a}}$ & $(23.46 \pm 32.54)^{\mathrm{a}}$ & $(756 \pm 341.17)^{\mathrm{a}}$ & \\
\hline \multirow[t]{2}{*}{ With grass } & $16.27-41.00$ & $1.78-8.10$ & $618-2528$ & 12 \\
\hline & $(24.65 \pm 9.45)^{\mathrm{a}}$ & $(4.24 \pm 2.11)^{b}$ & $(1257 \pm 684.69)^{\mathrm{b}}$ & \\
\hline Relative reversibility & $14.63 \%$ & $141 \%$ & $53 \%$ & \\
\hline \multicolumn{5}{|l|}{$>4 \%$ slope } \\
\hline \multirow[t]{2}{*}{ Control (without grass) } & $24.84-71.10$ & $13.70-92.42$ & $558-682$ & 5 \\
\hline & $(36.27 \pm 19.70)^{\mathrm{a}}$ & $(43.47 \pm 40.53)^{\mathrm{a}}$ & $(638 \pm 53.80)^{\mathrm{a}}$ & \\
\hline \multirow[t]{2}{*}{ With grass } & $7.85-14.06$ & $3.85-7.16$ & $891-1226$ & 5 \\
\hline & $(11.51 \pm 3.39)^{\mathrm{b}}$ & $(5.63 \pm 1.52)^{\mathrm{b}}$ & $(1071 \pm 121.13)^{\mathrm{b}}$ & \\
\hline Relative reversibility & $55.54 \%$ & $107 \%$ & $50.64 \%$ & \\
\hline
\end{tabular}

Table 6. Comparative comprehensive performance index of vegetative barrier.

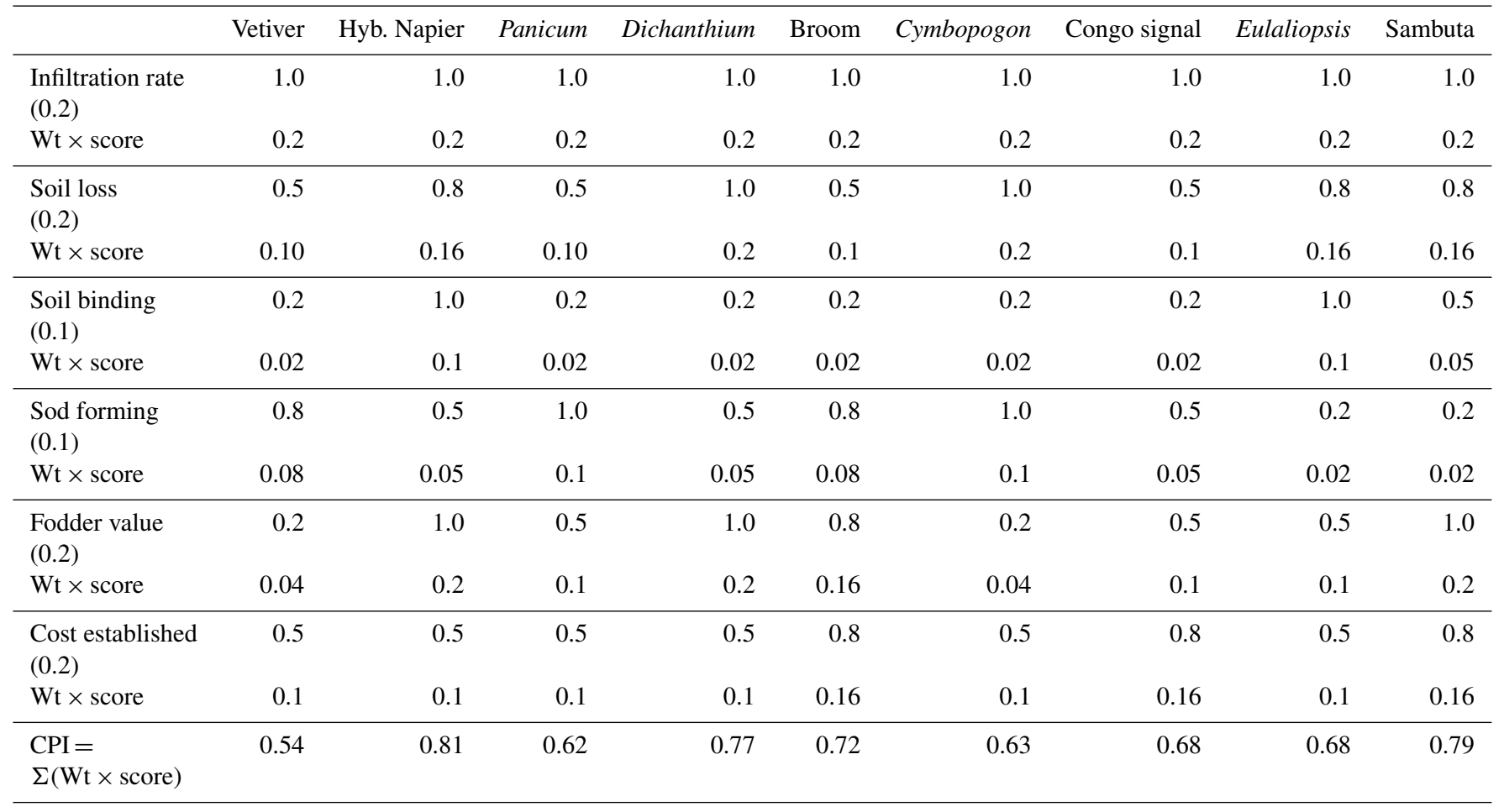

Values in the parentheses are weights assigned to the respective attributes. 


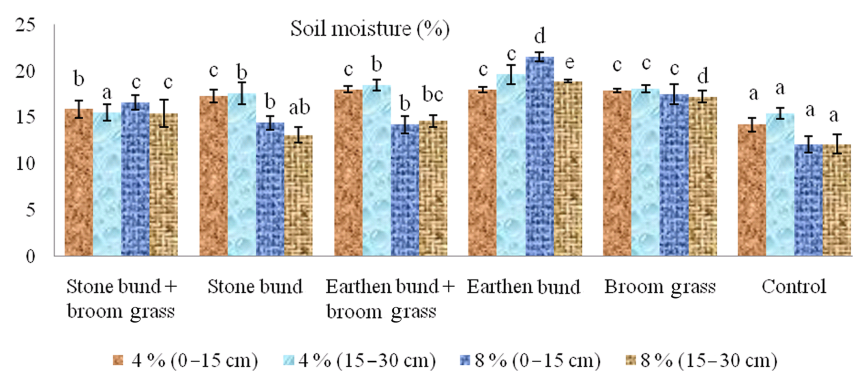

Figure 1. Complimentary role of grasses in enhancing soil profile moisture at 4 and $8 \%$ slope.

high as 12.6 adult cattle units per hectare $\left(\mathrm{ACU} \mathrm{ha}^{-1}\right)$, compared to the carrying capacity of $0.8 \mathrm{ACU} \mathrm{ha}^{-1}$ (GOI, 2015).

The data (Table 3 ) show that runoff varies between 11.30 and $33.40 \%$ with a mean value of $24.33 \%$ and soil loss varies between 1.52 and $3.28 \mathrm{Mg} \mathrm{ha}^{-1} \mathrm{yr}^{-1}$ with a mean value of $2.58 \mathrm{Mg} \mathrm{ha}^{-1} \mathrm{yr}^{-1}$ in control plots (without grazing management). The management of grazing lands (cut and carry system, rotational grazing and control grazing) significantly reduced the runoff ranging between 6.60 and $22.20 \%$ (with a mean value of $14.12 \%$ ) and soil loss ranging between 0.58 and $1.30 \mathrm{Mg} \mathrm{ha}^{-1} \mathrm{yr}^{-1}$ (with a mean value of $\left.0.95 \mathrm{Mg} \mathrm{ha}^{-1} \mathrm{yr}^{-1}\right)$. A total of 12 studies on grazing land management revealed that the benefits of stall feeding and controlled grazing could save about $42 \%$ water loss and $63 \%$ soil loss in sloppy lands. The mean runoff in grazing management practices was significantly reduced from 24.33 to $14.12 \%$. This may be due to higher green cover and biomass production under improved management. Grazing land management of Chrysopogon fulvus, Heteropogon contortus and Panicum maximum have shown the potential to produce $40,8.5$ and $110 \mathrm{Mg} \mathrm{ha}^{-1}$ green biomass yields, respectively (Rana, 1998; ICAR, 2006; Ghosh et al., 2009; Pathak and Dagar, 2015). The average soil loss was significantly reduced from 2.0 to $0.95 \mathrm{Mg} \mathrm{ha}^{-1} \mathrm{yr}^{-1}$ by the imposition of grazing and grassland practices. However, some researchers have demonstrated that grass steppes are more resistant to land degradation than shrub steppes (Palacio et al., 2014) and they contribute to increasing the biodiversity and improving the soil quality (Costa et al., 2015; Gao-Lin et al., 2016)

Dichanthium annulatum cover was found to reduce the runoff and soil loss by $35.45-51.40$ and $71.90-81.08 \%$, respectively, in slightly to severely degraded lands in lateritic soil of the Konkan region in India (Figs. 2 and 3). In this region Dichanthium annulatum yielded about $25-30 \mathrm{Mg} \mathrm{ha}^{-1}$ of green biomass under improved management. The investigation further suggested that carbon loss can be reduced to the extent of $88.36-83.12 \%$ in slightly and severely degraded lands in the same region (Fig. 4). The study also indicated that carbon sequestration rate up to $100 \mathrm{~kg} \mathrm{ha}^{-1} \mathrm{yr}^{-1}$ can be achieved by the use of grass strips running across the slope,

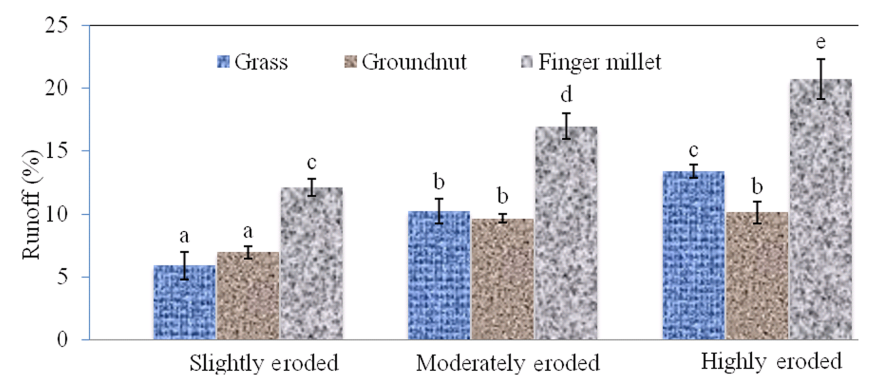

Figure 2. Impact of grasses in reducing runoff in lateritic soil.

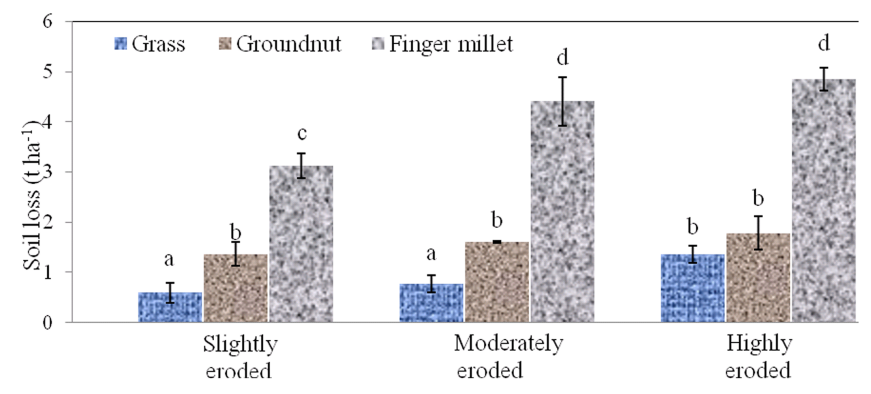

Figure 3. Impact of grasses in reducing soil loss in lateritic soil.

especially in laterite soils of the Konkan region (Kale et al., 1993). An about 6-fold increase in soil organic carbon (SOC) content in soil has been observed in barren lands of the Shivalik region through rehabilitation by Arundo donax. Grazing management typically leads to a $3 \%$ annual increase in soil carbon (Conant et al., 2001). Duran and Rodriguez (2008) showed that grasses provide perennial protection and minimal erosion as they provide complete ground cover (Brindle, 2003). In the Mediterranean region, based on 20 paired-plot studies, Keesstra et al. (2016) reported that runoff sediment concentration was 45.5 times higher in cleaned cultivation plots compared to covered plots. They further reported that erosion rate was below the soil loss tolerance limits under surface-covered conditions. It is noticeable that the loss of vegetation cover leads to increased surface instability and poor regeneration, which in turn set a vicious cycle in motion.

In the hilly region of northeastern Himalayas, the alternative land use systems help in reducing soil erosion systems and SOC loss to a substantial extent. Higher root biomass of the grasses, particularly Paspalum, Congo signal, and Panicum maximum var. Makunia and Hamil, due to greater water transmission resulted in higher SOC in the soil profile. Following addition of organic matter through continuous root decay of these grasses, water-holding capacity of the soil increased as a result of the increased specific surface area. Additionally, these grasses helped in improving soil quality, including soil hydro-physical characteristics and biological activities. Such improvement in soil properties have a direct bearing on $\mathrm{C}$ sequestration (5-fold increase in SOC over con- 


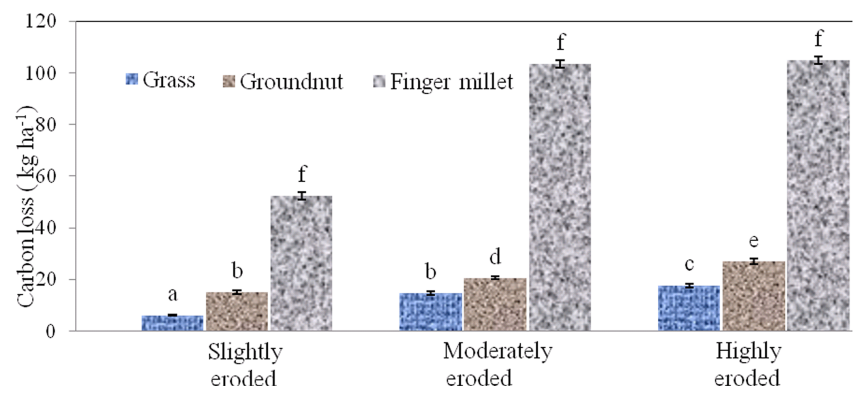

Figure 4. Impact of grasses in reducing carbon loss in lateritic soil.

trol), long-term sustainability and reducing soil erosion (23 -fold increase in structural stability over control) in a complex, risk-prone fragile ecosystem (Ghosh et al., 2009).

\section{Conclusions}

Human-induced changes due to land use intensification and overgrazing have caused some severe and extreme states of land degradation that may prove to be more difficult to restore under the ongoing practices. The present meta-analysis clearly revealed that suitable conservation measures, especially the vegetative and biological practices, greatly assist in reversing the land degradation process for both cropland and grasslands.

Most soil erosion control measures implemented in cultivated fields are physical structures. However, these physical structures were reported to be less acceptable due to the high cost of their construction and maintenance. The metaanalysis clearly showed that grass barriers potentially reduce runoff and soil loss by up to 86.8 and $97.32 \%$, respectively. The relative yield gained of various crops through CGBs at different slopes varied between 44 and $53 \%$. However, the effectiveness of grass barrier, as reported by several studies, is site-specific and depends mostly on slope gradient, runoff volume and flow rate, size and density of sediment particles, grass species, density, interval and width of grass strips, underlying soil properties, and rainfall intensity and duration. According to farmers' criteria based on CPI, the study revealed that Pennisetum purpureum was most preferred grass, followed by Saccharum munja and Dichanthium annulatum. Considering the CPI values it is apparent that Saccharum munja (sambuta) and Thysanolaena maxima (hill broom) are two important bio-remediation options for reclamation of shifting cultivation of the northeastern hill region and Eastern Ghats of India.

The present analysis also indicated that grass must be used as a vegetative strip to maintain soil quality in sloppy arable areas (8.5 Mha) of Indian hilly regions. Special emphasis on establishing grasses should be given to about 3 Mha of degraded pasture lands and 3.5 Mha of shifting cultivation areas in India to reverse the land degradation. Overall, we con- clude that the use of grass barriers alone or in combination with structural measures and grassland management was effective and efficient for decreasing soil and water loss on sloppy croplands in tropical and subtropical regions of India. Thus, these practices should be strongly recommended and used widely in similar climatic regions. Similarly, the reduction in grazing intensity needs to be advocated for about 12 Mha of permanent pasture lands.

Competing interests. The authors declare that they have no conflict of interest.

Acknowledgements. We owe our sincere thanks to the ICAR for funding this project (ICAR - National Fellow) and the director of the Indian Institute of Soil and Water Conservation (IISWC) for providing facilities and support.

Edited by: M. van der Ploeg

Reviewed by: two anonymous referees

\section{References}

Aggarwal, R. K., Yadav, R. P., Singh, P., and Shrama, P.: Impact of erosion on productivity. Annual Report 1999-2000, Central Soil \& Water Conservation Research and Training Institute, Dehradun, India, 16-17, 2000.

Ali, S., Parandiyal, A. K., Kumar, A., and Singh, R. K.: Cost effective conservation measures for management of medium and deep ravenous lands. Annual Report 2013-2014, Central Soil \& Water Conservation Research and Training Institute, Dehradun, India, 73-74, 2014.

Anigma, S.: Use of Calliandra-napier contour hedges to control soil erosion in central Kenya, Agr. Ecosyst. Environ., 91, 15-23, doi:10.1016/S0167-8809(01)00268-7, 2002.

ASAE: Crop production with conservation in the 80's, Proceedings of ASAE Conference on Crop Production in the 80's, ASAE, 12 December 1980, St. Joseph, MI 49085, USA, 1981.

Batjes, N. H.: Options for increasing carbon sequestration in West African soils: An exploratory study with special focus on Senegal, Land Degrad. Dev., 12, 131-142, 2001.

Becker, H.: Grass hedges to catch runway soil, Christiansen, J. R., 1942. Irrigation by Sprinkling-Bull. University of California, Agr. Res., 49, 21-121, 2001.

Beskow, S., Mello, C. R., Norton, L. D., Curi, N., Viola, M. R., and Avanzi, J. C.: Soil erosion prediction in the Grande River Basin, Brazil using distributed modelling, Catena, 79, 49-59, 2009.

Bhanavase, D. B., Deshpande, A. N., and Pawar, A. B.: Effect of vegetative barriers on resource conservation and productivity of sunflower (Helianthus annus L.) in inceptisols of Maharashtra, Indian J. Soil Conserv., 35, 238-241, 2007.

Bhardwaj, S. P. and Sindhwal, N. S.: Effect of vegetative barriers on runoff and soil loss in Doon valley, Indian J. Soil Conserv., 35, 266-267, 2007.

Bhatt, V. K., Tiwari, A. K., and Panwar, P.: Hydrological response to micro-catchments under different land uses with vegetation 
manipulation. Annual Report, 2012-2013, Central Soil \& Water Conservation Research and Training Institute, Dehradun, India, 56-57, 2013.

Biswas, H., Raizada, A., Mandal, D., Kumar, S., Srinivas, S., and Mishra, P. K.: Identification of areas vulnerable to soil erosion risk in India using GIS methods, Solid Earth, 6, 1247-1257, doi:10.5194/se-6-1247-2015, 2015.

Brindle, F. A.: Use of native vegetation and bio stimulants for controlling soil erosion on steep slope terrain, Transport Res. Rec., 1, 203-209, 2003.

Chand, M. and Bhan, S.: Effect of vegetative barrier on erosion losses, soil properties and yield of sorghum, Indian J. Soil Conserv., 28, 250-252, 2000.

Cogle, A. L., Keating, M. A., Langford, P. A., Gunton, J., and Webb, I. S.: Runoff, soil loss, and nutrient transport from cropping systems on Red Ferrosols in tropical northern Australia, Soil Res., 49, 87-97, doi:10.1071/SR10069, 2011.

Conant, R. J., Paustian, K., and Elliot, E. T.: Grassland Management and Conservation into Grassland: Effects on Soil Carbon, Ecol. Appl., 11, 343-355, 2001.

Costa, C. E. M., Papatheodorou, N., Monokrousos, and Stamou, G. P.: Spatial Variability of Soil Organic C, Inorganic N and Extractable $\mathrm{P}$ in a Mediterranean Grazed Area, Land Degrad. Dev., 26, 103-109, doi:10.1002/ldr.2188, 2015.

De Oliveria, P. T. S., Sobrinho, T. A., Rodrigues, D. B. B., and Panachuki, E.: Erosion Risk mapping applied to environmental zoning, Water Resour. Manag., 25, 1021-1036, doi:10.1007/s11269-010-9739-0, 2010.

Dhruvanarayana, V. V. and Rambabu.: Estimation of soil erosion in India, J. Irrig. Drain. E.-ASCE, 109, 419-434, doi:10.1061/(ASCE)0733-9437(1983)109:4(419), 1983.

Duran, Z. V. H. and Rodrignez, P. C. R.: Soil erosion and runoff prevention by plant covers. A review, Agron. Sustain. Dev., 28, 65-86, 2008.

Fisher, R. A.: The design of experiments, 1st edn., Oliver and Boyd, Edinburgh and London, UK, 1935.

Gao-Lin, W. W., Dong, L., Yu, D., Lu-Ming, D., and Zhen-Heng, L.: Warm-Season Grazing Benefits Species Diversity Conservation and Topsoil Nutrient Sequestration in Alpine Meadow, Land Degrad. Dev., doi:10.1002/ldr.2536, in press, 2016.

Ghosh, P. K., Saha, R., Gupta, J. J., Ramesh, T., Das, A., Lama, T. D., Munda, G.C., Bordoloi, J. S., Verma, M. D., and Ngachan., S.V.: Long-term effect of pastures on soil quality in acid soil of North-East India, Aust. J. Soil Res., 47, 372-379, doi:10.1071/SR08169, 2009.

Gilley, J. E., Eghball, B., Kramer, L. A., and Moorman, T. B.: Narrow grass hedge effects on runoff and soil loss, J. Soil Water Conserv., 55, 190-196, 2000.

GOI: There is Need of Strong Services Sector in Rural India. Press information Bureau, Ministry of Agriculture, available at: http:// pib.nic.in/newsite/PrintRelease.aspx?relid=131734 (last access: 28 November 2016), 2015.

Grunder, M.: Soil conservation research in Ethiopia, in: Land Conservation for Future Generations, edited by: Rinnwanich, J., Proceedings of the Fifth International Soil Conservation Conference, 18-29 January 1988, Department of Land Development, Bangkok 10900, Thailand, 901-911, 1988.
Hazra, C. R. and Singh, P.: Grasslands in India and their role in livestock production and Soil conservation, Indian J. Soil Conserv., 14, 73-83, 1986.

Hu, G., Liu, H., Yin, Y., and Song, Z.: The Role of Legumes in Plant Community Succession of Degraded Grasslands in Northern China, Land Degrad. Dev., 27, 366-372, doi:10.1002/ldr.2382, 2016.

Huang, D., Han, J. G., Wu, J. Y., Wang, K., Wu, W. L., Teng, W. J., and Sardo, V.: Grass hedges for the protection of sloping lands from runoff and soil loss: An example from Northern China, Soil Till. Res., 110, 251-256, doi:10.1016/j.still.2010.08.013, 2010.

Hudson, N. W.: Soil Conservation, Batsford, London, UK, p. 320, 1981.

ICAR: Forage and grasses, in: Handbook of Agriculture. Directorate of Information and publications of Agriculture. Indian Council of Agricultural Research, New Delhi, 128-1161, available at: http://www.icar.org.in/files/forageandgrasses.pdf (last access: 4 December 2016), 2006.

Ilango, K., Rao, M. S., Mohan, R., and Reddy, K. K.: Comparative effectiveness of different grass species in reducing runoff and soil loss. Annual Report 2001-2002, Central Soil \& Water Conservation Research and Training Institute, Dehradun, India, 48, 2002.

Ilstect, U., Malmer, A., Verbeeten, E., and Murdiyarso, D.: The effect of afforestation on water infiltration in the tropics; a systematic review and meta-analysis, Forest Ecol. Manag., 251, 45-51, doi:10.1016/j.foreco.2007.06.014, 2007.

Jajannathan, R., Rangaraju, G. H., Vijayaraghavan, H., and Wilfred, M. W.: Performance of vetiver barriers in conserving soil moisture at different levels of planting, in: Second International Veteiver Workshop, 18-22 January 2000, Phetchaburi, Thailand, 2000.

Janushaj, A.: Investigation on soil erosion-evaluation of the protective action of vetiver grass hedges, unpublished MSc thesis, CIHEAM, Mediterranean Agronomic Institute of Bari, Italy, 2005.

Jha, P., Nitant, H., and Mandal, D.: Establishing Permissible Erosion rates for various landforms in Delhi state, India, Land Degrad. Dev., 20, 92-100, doi:10.1002/ldr.886, 2009.

Kagabo, D. M., Stroosnijder, L., Visser, S. M., and Moore, D.: Soil erosion, soil fertility and crop yield on slow-forming terraces in the highlands of Buberuka, Rwanda, Soil Till. Res., 128, 23-29, doi:10.1016/j.still.2012.11.002, 2013.

Kale, S. R., Salve, V. G., Varade, P. A., and Kadrekar, S. B.: Abstracts of national seminar on developments in soil science, 58th annual convention, ISSS, held at: CSWCR \& TI (now renamed as ICAR - Indian Institute of Soil and Water Conservation), 610 October 1993, Dehradun, Uttarakhand, India, 1993.

Katiyar, V. S., Lal, B., and Narayan, D.: Soil conservation measures in red arable soils. Annual Report 2006-2007, Central Soil \& Water Conservation Research and Training Institute, Dehradun, India, 41-42, 2007a.

Katiyar, V. S., Narayan, D., and Lal, B.: Evaluation of mechanical and vegetative measures on filed size runoff plots. Annual Report 2006-2007, Central Soil \& Water Conservation Research and Training Institute, Dehradun, India, 61, 2007b.

Keesstra, S. D., Maroulis, J., Argaman, E., Voogt, A., and Wittenberg, L.: Effects of controlled fire on hydrology and erosion under simulated rainfall, Cuadernos de Investigación Geográfica, 40, 269-293, doi:10.18172/cig.2532, 2014. 
Keesstra, S. D., Pereira, P., Novara, A., Brevik, E. C., AzorinMolina, C., Parras-Alcantara, L., Jordan, A., and Cerda, A.: Effects of soil management techniques on soil water erosion in Apricot orchards, Sci. Total Environ., 551-552, 357-366, doi:10.1016/j.scitotenv.2016.01.182, 2016.

Khola, O. P. S.: Biological and mechanical measures for erosion control and crop production. Annual Report 1999-2000, Central Soil \& Water Conservation Research and Training Institute, Dehradun, India, 30-33, 2000.

Khola, O. P. S.: Silvipastoral approach to improve productivity of native pastures for livestock production in hills NATP. Annual Report 2003-2004, Central Soil \& Water Conservation Research and Training Institute, Dehradun, India, 51-52, 2004.

Khola, O. P. S. and Sastry, G.: Conservation efficiency of mechanical measures and productivity of maize-wheat cropping sequence under different land slopes in foothills of western Himalaya, Indian J. Soil Conserv., 33, 221-224, 2005.

Kumar, M.: North East India: soil and water management imperatives for food security in a changing climate, Curr. Sci. India, 101, 1119, 2011.

Laing, D. R. and Ruppenthal, M.: Vetiver News Letter No. 8, Asia Technical Department, The World Bank, Washington, DC, USA, 1991.

Lal, B., Narayan, D., and Katiyar, V. S.: Assessing crop cover influence on runoff and soil loss for red soils of Bundelkhand. Annual Report 2003-2004, Central Soil \& Water Conservation Research and Training Institute, Dehradun, India, 18-19, 2004.

Lal, R.: Soil erosion impact on agronomic productivity and environment quality, Crit. Rev. Plant Sci., 17, 319-464, 1998.

Madhu, M., Muralidharan, P., Sahoo, D. C., and Chand, S.: Development and evaluation of conservation measures and land use systems for sustainable crop production in Western Ghats of coastal region. Annual Report 2003-2004, Central Soil \& Water Conservation Research and Training Institute, Dehradun, India, 36-39, 2004.

Mandal, D. and Jayaprakash, J.: Water repellency of soils in the lower Himalayan regions of India: impact of land use, Curr. Sci. India, 96, 148-150, 2009.

Mandal, D. and Sharda, V. N.: Land Classification Employing Integrated Bio-physical Approach for Sustainable Land Use, J. Ind. Soc. Soil Sci., 59, 218-223, 2011 a.

Mandal, D. and Sharda, V. N.: Assessment of permissible soil loss in India employing a quantitative bio-physical model, Curr. Sci. India, 100, 383-390, 2011b.

Mandal, D. and Sharda, V. N.: Appraisal of soil erosion risk in the eastern Himalayan region of India for soil conservation planning, Land Degrad. Dev., 24, 430-437, doi:10.1002/ldr.1139, 2013.

Mandal, D., Dadhwal, K. S., Khola, O. P. S., and Dhyani, B. L.: Adjusted $\mathrm{T}$ values for conservation planning in Northwest Himalayas of India, J. Soil Water Conserv., 61, 391-397, doi:10.1080/00221349308979120, 2006.

Mandal, D., Singh, R., Dhyani, S. K., and Dhyani, B. L.: Landscape and land use effects on soil resources in a Himalayan watershed, Catena, 81, 203-208, doi:10.1016/j.catena.2010.03.004, 2010.

Mekonnen, M., Keesstra, S. D., Ritsema, C. J., Stroosnijder, L., and Baartman, J. E. M.: Sediment trapping with indigenous grass species showing differences in plant traits in northwest Ethiopia, Catena, 147, 755-763, 2016.
Mishra, P. J. and Sahu, D.: Comparative performance of vegetative barrier in north eastern ghat zone of Orissa, Indian J. Soil Conserv., 29, 50-52, 2001.

Misri, B.: Migratory goat and sheep rearing in Himanchal Pradesh, India, in: Transumant grazing system in Temperate Asia, edited by: Suttie, J. M. and Reynolds, S. G., FAO, Rome, Italy, 331, 2003.

MoEF: National forest action programme, vol 1., Ministry of Environment and Forest, New Delhi, India, 179, 1999.

Mulugeta, T.: Soil Conservation Experiments on Cultivated Land in the Maybar Area, Wello Region, Ethiopia. Soil Conservation Research Project, Research Report No. 16. University of Berne, Switzerland, 127, 1988.

Mutegi, J. K., Mugendi, D. N., Verchot, L. V., and Kung'u, J. B.: Combining napier grass with leguminous shrubs in contour hedgerows controls soil erosion without competing with crops, Agrofor. Syst., 74, 37-49, doi:10.1007/s10457-008-91523, 2008 .

Nalatwadmath, S. K., Rao, M. S., and Rama, M.: Runoff, soil and nutrient losses under different vegetative covers in $2 \%$ slope of black soil. Annual Report 1999-2000, Central Soil \& Water Conservation Research and Training Institute, Dehradun, India, 2122, 2000

Narain, P., Chaudhary, R. S., and Singh, R. K.: Efficacy of conservation measures in northern hilly regions, Indian J. Soil Conserv. 22, 42-62, 1994.

Narayan, D., Biswas, H., and Kumar, P.: Conservation measures for resource conservation and enhancing yield of sorghum (Sorghum bicolor L.) in red soils of Bundelkhand region in central India, Indian J. of Soil Conserv., 42, 62-67, 2014.

Nearing, M. A., Jetten, V., Baffaut, C., Cerda, A., Hernandez, M., Le Bissonnais, Y., Nichols, M. H., Nunes, J. P, Renschler, C. S., Souchere, V., and Van Oost, K.: Modeling response of soil erosion and runoff to changes in precipitation and cover, Catena, 61, 131-154, doi:10.1016/j.catena.2005.03.007, 2005.

Njoroge, M. and Rao, M. R.: Barrier Hedgerow intercropping for soil and water conservation on sloping lands, in: Soil and Water Conservation-Challenges and opportunities, 8th ISCO proceedings, 4-8 December 1994, New Delhi, 1994.

Novara, A., Gristina, L., Saladino, S. S., Santoro, A., and Cerdà, A.: Soil erosion assessment on tillage and alternative soil managements in a Sicilian vineyard, Soil Till. Res., 117, 140-147, 2011.

Novara, A., Gristina, L., Guaitoli, F., Santoro, A., and Cerdà, A.: Managing soil nitrate with cover crops and buffer strips in $\mathrm{Si}$ cilian vineyards, Solid Earth, 4, 255-262, doi:10.5194/se-4-2552013, 2013.

Novara, A., Keesstra, S., Cerdà, A., Pereira, P., and Gristina, L.: Understanding the role of soil erosion on $\mathrm{CO}_{2}-\mathrm{C}$ loss using ${ }^{13} \mathrm{C}$ isotopic signatures in abandoned Mediterranean agricultural land, Sci. Total Environ., 550, 330-336, doi:10.1016/j.scitotenv.2016.01.095, 2016.

Ochoa, P. A., Fries, A., Mejía, D., Burneo, I., Ruíz-Sinoga, J. D., and Cerdà, A.: Effects of climate, land cover and topography on soil erosion risk in a semiarid basin of the Andes, Catena, 140, 31-42, doi:10.1016/j.catena.2016.01.011, 2016.

Ojasvi, P. R., Khola, O. P. S., and Dogra, P.: Evaluation of mechanical and vegetative measures on $8 \%$ slope. Annual Report 1999_ 
2000. Central Soil \& Water Conservation Research and Training Institute, Dehradun, India, 28-29, 2000.

Ola, A., Dodd, I. C., and Quinton, J. N.: Can we manipulate root system architecture to control soil erosion?, SOIL, 1, 603-612, doi:10.5194/soil-1-603-2015, 2015.

Osenberg, C. W., Sarnelle, O., Copper, S. D., and Holt, R.: Resolving ecological questions through meta-anlysis: goals, metrics and models, Ecology, 80, 1105-1117, doi:10.2307/177058, 1999.

Palacio, R. G., Bisigato, A. J., and Bouza, P. J.: Soil erosion in three grazed plant communities in Northeastern Patagonia, Land Degrad. Dev., 25, 594-603, doi:10.1002/ldr.2289, 2014.

Parras-Alcántara, L., Díaz-Jaimes, L., and Lozano-García, B.: Management Effects on Soil Organic Carbon Stock in Mediterranean Open Rangelands-Treeless Grasslands, Land Degrad. Dev., 26, 22-34, doi:10.1002/ldr.2269, 2015.

Pathak, P. S. and Dagar, J. C.: Indian grasslands and their management, in: Grassland: A Global Resource perspective, edited by: Goosh, P. K., Mahanta, S. K., Singh, J. B., and Pathak, P. S., Range management Society of India, Jhansi, India, 3-36, 2015.

Patil, Y. M., Belgaumi, M. I., Maurya, N. L.,Kusad, V. S., Mansur, C. P., and Patil, S. L.: Economic evaluation of different barriers on growth and yield of rabi sorghum, Indian J. Soil Conserv., 23, 86-87, 1995.

Pimentel, D.: World Soil Erosion and Conservation, Cambridge University Press, Cambridge, UK, 1993.

Poeplau, C. and Don, A.: Carbon sequestration in agricultural soil via cultivation of cover crops- a meta-analysis, Agr. Ecosyst. Environ., 200, 33-41, doi:10.1016/j.agee.2014.10.024, 2015.

Prakash, C., Raizada, A., Samra, J. S., and Sastry, G.: Vegetative barriers for resource conservation, Technical Bulletin No. T41/D-29, Central Soil and Water Conservation Research and training Institute (ICAR), 218, Kaulagarh Road, Dehradun, Uttarakhand, India, p. 111, 1999.

Prasad, S. N., Singh, R. K., Shakir, A., and Parandiyal, A. K.: Comparative performance of grass barriers on erosion and crop yields in medium black soils of Kota, Indian J. Soil Conserv., 33, 58-61, 2005.

Prosdocimi, M., Cerdà, A., and Tarolli, P.: Soil water erosion on Mediterranean vineyards: A review, Catena, 141, 1-21, doi:10.1016/j.catena.2016.02.010, 2016.

Rachman, A., Anderson, S. H., Gantzer, C. J., and Thompson, A. L.: Influence of stiff stemmed hedge system on infiltration, Soil Sci. Soc. Am. J., 68, 2000-2006, 2004a.

Rachman, A., Anderson, S. H., Gantzer, C. J., and Alberts, E. E.: Soil hydraulic properties influenced by stiff-stemmed grass hedge system, Soil Sci. Soc. Am. J., 68, 1386-1393, 2004b.

Rachman, A., Anderson, S. H., and Gantzer, C. J.: Computedtomographic measurement of soil macroporosity parameters as affected by stiff-stemmed grass hedges, Soil Sci. Soc. Am. J., 69, 1609-1616, 2005.

Rana, R. S.: Evaluation of engineering and vegetative measures for gully control in khnadi region of Himanchal Pradesh, Indian J. Soil Conserv., 26, 219-225, 1998.

Rao, B. K. and Pande, V. C.: Effectiveness of vegetative filter strips (VFS) in preventing soil and nutrient losses. Annual Report 2013-2014, Central Soil \& Water Conservation Research and Training Institute, Dehradun, India, 14-16, 2014.
Rao, K. P. C, Cogle, A. L., and Srivastava, K. L.: Conservation effects of porous and vegetative barriers. ICRISAT, Annual Report, Patancheru, Andhra Pradesh, 502 234, India, 1991.

Rao, K. S. and Pant, R.: Land use dynamics and landscape change pattern in a typical micro watershed in the mid elevation zone of central Himalaya, India, Agr. Ecosyst. Environ., 86, 113-124, doi:10.1016/S0167-8809(00)00274-7, 2001.

Rao, M. S., Mohan, R., Patil, S. L., and Nalatwadmath, S. K.: Effect of different agronomic and mechanical measures in reducing soil and water losses in black soils. Annual Report 1997-1998, Central Soil \& Water Conservation Research and Training Institute, Dehradun, India, 84-86, 1998.

Rao, M. S. R. M. and Reddy, K. K.: ORP Chinnatekur, Annual report, 1995-96, Central Soil \& Water Conservation Research and Training Institute, Dehradun, Uttarakhand, India, 117-119, 1996.

Rodrigo Comino, J., Iserloh, T., Lassu, T., Cerdà, A., Keesstra, S. D., Prosdocimi, M., Brings, C., Marzen, M., Ramos, M. C., Senciales, J. M., Ruiz Sinoga, J. D., Seeger, M., and Ries J. B.: Quantitative comparison of initial soil erosion processes and runoff generation in Spanish and German vineyards, Sci. Total Environ., 565, 1165-1174, doi:10.1016/j.scitotenv.2016.05.163, 2016.

Rodriguez, O. S.: Hedgerows and mulch as soil conservation measures evaluated under field simulated rainfall, Soil Technol., 11, 79-93, doi:10.1016/S0933-3630(96)00117-1, 1997.

Roy, A. K. and Singh, J. P.: Grasslands in India: Problems and perspectives for sustaining livestock and rural livelihoods, Trop. Grasslands, 1, 240-243, 2013.

Sahay, K. B.: Problem of livestock population, New Delhi, The tribune, http://www.tribuneindia.com/2000/20000411/edit. htm (last access: 20 December 2016), 11 April 2000.

Sahoo, D. C. and Adhikary, P. P.: Bio-engineering measures for resource conservation and management in red sloppy lateritic soils of Orissa. Annual Report 2013-2014, Central Soil \& Water Conservation Research and Training Institute, Dehradun, India, 5153, 2014.

Senapati, S. C. and Sharma, S. D.: Effect of buffer strips on soil erosion and yield of maize (Zea mays L.) in rainfed slopy uplands in north-western plateau zone of Orissa, Indian J. Soil Conserv., 35, 47-49, 2007.

Seutloali, K. E. and Beckedahl, H. R.: Understanding the factors influencing rill erosion on roadcuts in the south eastern region of South Africa, Solid Earth, 6, 633-641, doi:10.5194/se-6-6332015, 2015.

Sharda, V. N., Shrimali, S. S., and Khola, O. P. S.: Hydrological evaluation of recommended conservation measures on mildly sloping lands. Annual Report 2001-2002, Central Soil \& Water Conservation Research and Training Institute, Dehradun, India, 56-57, 2002.

Sharma, A. K.: Runoff, soil loss and nutrient losses under different crop covers and red soils of Datia (2\%) slope. Annual Report 1997-1998, Central Soil \& Water Conservation Research and Training Institute, Dehradun, India, 90-91, 1999.

Sharma, A. K. and Bhatt, V. K.: Evaluation of farming systems and practices for sustainability in black soils. Annual Report 19951996, Central Soil \& Water Conservation Research and Training Institute, Dehradun, India, 127-129, 1997.

Shrimalli, S. S.: Hydrological characterization of commonly identified vegetative species for vegetative barrier. Annual Report 
1999-2000, Central Soil \& Water Conservation Research and Training Institute, Dehradun, India, 29-30, 2000.

Subudhi, C. R. and Senapati, P. C.: Runoff and soil loss under different vegetative measures in Kalahandi district of Orissa, Indian J. Soil Conserv., 24, 177-179, 1996.

Subudhi, C. R., Pradhan, P. C., and Senapati, P. C.: Effect of vegetative barrier on soil erosion sand yield of rice in easter ghats, Indian J. Soil Conserv., 26, 95-98, 1998.

Sudhishri, S., Dass, A., and Lenka, N. K.: Efficacy of vegetative barriers for rehabilitation of degraded hills slopes in eastern India, Soil Till. Res., 99, 98-107, 2008.

Tangtumniyom, N., Chalothorn, C., and Prasitnork, P.: Effect of vetiver hedges on runoff, soil moisture and yield of rain fed crops in the alfisol of watersheds of Southern India.Paper presented at ICV-1, Abstracts, ORDPB, Bangkok, p. 75, 1996.
Tripathi, R. P. and Singh, H. P.: Soil Erosion and Conservation, Willey Eastern Limited, New Delhi, India, 1993.

Turkelboom, F., Ongprasert, S., and Taejajai, U.: Fertile strips along steep slopes: sustainability of alley cropping and indigenous soil conservation techniques, in: Proceedings of 8th International Soil Conservation Conference, New Delhi, India, edited by: Bhushan, L. S., Abrol, I. P., and Rama, M. S., Indian Association of Soil and Water Conservationists, Dehra Dun, India, 496-509, 1994.

Welle, S., Chantawarangul, K., Nontananandh, S., and Jantawat, S.: Effectiveness of Grass Strips as Barrier Against Runoff and Soil Loss in Jijiga Area, Northern Part of Somali Region, Ethiopia Kasetsart, J. Nat. Sci., 40, 549-558, 2006. 